IBAD, 2020; (6): 344-365

\title{
Markaların Sosyal Medyada Gündem Kullanımı: Gerçek Zamanlı Reklamlar
}

\section{Dr.öğr.Üyesi Yasemin Bozkurt ${ }^{\text {* }}$}

Geliş tarihi: 31.12 .2019

Kabul tarihi: 25.01.2020

\section{Atıf bilgisi: \\ IBAD Sosyal Bilimler Dergisi \\ Sayı: $6 \quad$ Sayfa: $344-365$ \\ Yıl: 2020 Dönem: Kıs}

This article was checked by iThenticate. Similarity Index $2 \%$

Bu makalede araştırma ve yayın etiğine uyulmuştur.

1Pamukkale Üniversitesi, İletişim Fakültesi, Halkla İlișkiler ve Tanıtım Bölümü, Türkiye, ybozkurt@pau.edu.tr ORCID ID 0000-0001-8183-0337

* Sorumlu yazar
$\ddot{O} \mathbf{Z}$

İletişim uygulamaları, gündem belirleme kuramı temelinde çeşitli yönlendirici ve ikna mekanizmalarını kullanarak belirli konularla ilgili kamuoyu oluşturup gündemi belirleyebilmektedir. Özellikle sosyal medya ortamlarının kullanılmaya başlamasıyla birlikte, iletişim uygulamaları aracılığıyla gündemi etkileyebilmek, çok daha hızlı ve etkili olabilmektedir. Markalar da ürünlerini ya da işletmelerini tüketici gündemine alabilmek ve ilgilerini çekebilmek için, gerçek zamanlı gündemin içeriğiyle markanın kendisini ya da ürün özelliğini birleştirerek reklam mesajına dönüștürmektedir. Reklamda gündem kullanımı, medya araçlarının yönlendiriciliği olarak değil; gündemi reklam mesajına dönüştürerek, tüketicinin gerçek gündeme yoğunlaşmış ilgisini markaya çekip, gündeme markanın yerleştirilmesiyle yapılmaktadır. Uygulamanın markalara önemli kazanımlar sunması, birçok markanın gerçek zamanlı reklam çalışması yapmasına neden olmuștur. Gündem konusu marka ve ürüne uygun olsun olmasın, rakiplerinden geri kalmamak ya da rakiplerin önüne geçebilmek için, markalar hemen bu reklam uygulamasını tasarlayıp paylaşmaktadır. Özellikle planlı olmayan gündemden faydalanma durumu söz konusu olduğunda, çarçabuk yapılan uygulamalardaki reklam mesajının, görsel ve yazılı içeriklerinin gündem konusuyla uyumluluğu konusunda çeşitli problemler yaşanabilmektedir. Bu bağlamda çalışmanın amacı; gerçek zamanlı reklamların temel bileşenlerini ortaya koyarak, bu reklamların dayandığı kurama uygun olarak kullanılıp kullanılmadığını, aktarılmak istenen mesaj doğrultusunda tasarlanan görsel ve yazılı içeriklerin gündem konusuyla uyumlu olup olmadığını belirlemektir. $\mathrm{Bu}$ amaç doğrultusunda 2015 yılında yaşanan elektrik kesintisini gündem konusu olarak seçen markaların bu konu temelinde geliștirdikleri Twitter reklamlarına içerik analizi uygulanmıştır. 70 adet gerçek zamanlı reklamın incelendiği çalışmanın bulgularına göre, markalar genel olarak ürün/hizmetleriyle ilgili bilgi vermek için bu uygulamaları yapmaktadır. Markaların genel olarak görsel ve yazılı içeriği birlikte kullanmayı tercih ettiği Twitter reklamlarına ait içerik özelliklerinin; gündem konusuyla uyumlu ve stratejik açıdan doğru reklam tasarladıkları görülmektedir. Dahası reklamlarda kullanılan gündem konusuyla ürünlerin uyumlu olmadıkları, buna karşılık reklam mesajının, yazılı ve görsel içeriğin gündemle yüksek uyumlu olduğu; diğer taraftan yazılı içerikle gündem konusu arasında hiç ilişki olmayan reklam oranının da yüksek olduğu belirlenmiştir.

Anahtar kelimeler: Gerçek zamanlı reklamlar, gündem, gündem oluşturma kuramı, sosyal medya, Twitter, uyum. 


\title{
Agenda Use of Brands in Social Media: Real Time Advertising
}

\author{
Assist. Prof. Dr. Yasemin Bozkurt ${ }^{1^{*}}$
}

First received: 31.12 .2019

Accepted: 25.01 .2020

Citation:

IBAD Journal of Social Sciences

Issue: $6 \quad$ Pages: 344-365

Year: $2020 \quad$ Session: Winter

This article was checked by iThenticate. Similarity Index $2 \%$

1Pamukkale University, Communication Faculty, Public Relations and Publicity Department, Turkey, ybozkurt@pau.edu.tr ORCID ID 0000-0001-8183-0337

\section{* Corresponding Author}

\begin{abstract}
Communication practices can create public opinion on specific issues and set the agenda by using various guiding and persuasive mechanisms for agenda setting theory. Especially with the introduction of social media, being able to influence the agenda through communication applications can be much faster and more effective. Brands, in order to bring their products or businesses to the consumer agenda and attract their interest, combine the content of the real-time agenda with the brand itself or product features and turn them into advertising messages. The use of the agenda in advertising is not used for the guidance of the media. The use of the agenda in advertising is made by converting the agenda into an advertising message, attracting the attention of the consumer to the real agenda and placing the brand on the agenda. The fact that the application provides significant gains to brands has led many brands to perform real-time advertising. Whether or not the brand and product is suitable for the agenda, the brands immediately design and share this advertising application in order to stay ahead of their competitors or to surpass their competitors. Particularly when it comes to making use of the unplanned agenda, there may be problems with the compatibility of the visual and textual content of the advertisement with the agenda, due to the advertising message in hasty applications. The aim of this study is; to determine the basic components of real-time advertisements, whether these advertisements are used in accordance with the theory on which they are based, and whether the visual and written content designed in line with the desired message is compatible with the agenda. For this purpose, content analysis was applied to the Twitter advertisements developed by brands that chose the power outage in 2015 as the subject of the agenda. According to the findings of the study in which 70 realtime advertisements were examined, brands generally make these applications to provide information about their products / services. The content characteristics of Twitter advertisements, in which brands generally prefer to use visual and written content together; It is seen that they have designed the right advertisement in line with the agenda issue. Moreover, the agenda is not compatible with the products used in advertising, whereas the advertising message, written and visual content is highly compatible with the agenda; On the other hand, it was determined that the advertising rate, which had no relation between the written content and the agenda, was high.
\end{abstract}

Key words: Real time advertising, agenda, agenda theory, social media, Twitter, congruent. 


\section{GİRIS}

Markalar sosyal medya ortamlarında hedef kitlelerine ulaşmak ve hedeflerini gerçekleștirmek için sürekli yenilikçi, çok farklı reklam uygulamalarının arayışı içerisinde bulunmaktadırlar. Geleneksel reklam uygulamalarının yanı sıra, sosyal medya ortamlarında hedef kitlelerin dikkat ve ilgisini çekerek etkileşim içerisine girebilecekleri reklam uygulamalarını her geçen gün daha fazla kullanmayı tercih etmektedirler. Diğer taraftan sosyal medya ortamı dahi olsa, diğer iletişim hedefleri bir tarafa, tüketicilerin dikkat ve ilgilerini çekmek her an daha fazla güçleşmektedir. Çünkü milyonlarca hatta milyarlarca insanın kullandığı bu ortamlarda hem birçok kurum ve kuruluş insanların, hem de insanlar birbirlerinin aynı anda dikkatini çekmeye, söylediklerine ya da yazdıklarına başkalarının ilgi duymalarını sağlamaya çalışmaktadır. Üstelik bir sosyal medya kullanıcısına saniyeler içinde bu mesajlardan onlarcası ulaşmaya çalışmaktadır.

Böyle bir mesaj kirliliği içerisinde markalar kendilerine yönelik farkındalığı sağlamak için dayanakları eskiye, ama tasarımı yeni teknolojilere bağlı uygulamaları, çözüm yolu olarak kullanmaktadır. Son dönemlerde çok dikkat çeken, başarılı yapıldığında yüksek etkileşim gerçekleştiren, ağızdan ağıza yayılma potansiyeli beklentileri karşılayacak boyutlara ulaşan uygulamalardan birisi de gerçek zamanlı reklam uygulamalarıdır. Gerçek zamanlı reklamların temeli esasında gündem oluşturma kuramına dayanmaktadır. Bu kuram, medyanın bireylerin ilgileneceği ve yorumlayabileceği, dolayısıyla toplumun gündemini oluşturacak konuları belirleyerek hangi konu/olay hakkında düşünüp diğerleriyle paylaşımda bulunacağına yön verebileceğini ve böylece kamuoyunu istediği biçimde şekillendirebileceğini vurgulamaktadır. Kurama göre; medya sahipleri toplumda kendileri için önemli ve öncelikli konuları belirleyip çeşitli sunum biçimlerini kullanarak bu konuları, toplumun gündemi haline getirmeye çalışmaktadır ve çoğu zaman bu durumu başarmaktadır.

Markalar da medyanın bu kuram temelinde yapmayı başardığı süreci kendileri için kullanarak, kendisinin ya da ait oldukları işletmelerin gündeme gelmesi için yapmaktadırlar. Reklamcılık perspektifinden baktığımızda markalar yaptıkları yaratıcı ve farklı reklamlar aracılığıyla tüketicilerin ilgisini çekerek bir anda gündemin kendisini oluşturabildiği gibi, bazen de görsel ya da yazılı olarak reklam mesajını gündemdeki konular temelinde dönüştürerek gündem haline gelebilmektedir. Gündem konularından yararlanarak gündeme gelmek için de ya zaten toplumun gündemine yerleşmiş, üzerinde konuşulan, popüler olan bir konuyu yaratıcı bir biçimde marka mesajıyla bütünleştirmekte ya da önemli günleri firsat olarak değerlendirip daha önceden planlayarak yaratıcı bir biçimde bu özel günün anlamını marka mesajıyla birleştirmektedir. Böylece tasarlanan bu reklam mesajı aracılığıyla toplumun zihnindeki konuya yönelik gündemi, marka gündemi haline getirmeye çalışmaktadır.

Burada önemli olan insanların merak edip ilgi duyacakları ama aynı zamanda ürün kategorisi ve marka kimliğiyle uyumlu olabilecek gündem konusunun belirlenmesi; aynı gündem konusuyla uyumlu hem görsel hem de yazılı reklam mesajlarının tasarlanmasıdır. Diğer taraftan küçük, orta ya da büyük ölçekli birçok işletme markalarının, gerçek zamanlı reklam uygulamalarını yoğun düzeyde kullandığı görülmektedir. Ancak tasarlanan bu reklam uygulamalarının özelliklerinden yola çıkarak, gündem oluşturma kuramına uygun kullanılıp kullanılmadığı, gündem konusuyla uyumlu ve bağlantılı tasarlanıp tasarlanmadığı bilinmemektedir. Yapılan bu çalışma, gerçek zamanlı reklamların kullanım durumlarını çok yönlü açıklamak amacıyla yapılmaktadır. Bu bağlamda çalışmada öncelikle gerçek zamanlı reklamların dayanak noktasını oluşturan gündem belirleme kuramı açıklanmakta, ardından markaların bu kuramı nasıl kullandığı, gerçek zamanlı reklamların ne olduğu ve başarılı uygulamaların özellikleri ifade edilmekte, sonrasında da araştırma süreciyle bulgu ve sonuçlar aktarılmaktadır.

\section{LITERATÜR ANALIZI}

\section{Sosyal Medya Ortamında Gündem Oluşturma Kuramından Marka İletişimine}

İnsanlar dikkatlerini çeken, ilgi duydukları konu ya da olaylar hakkında düşünmekte, düşüncelerini paylaşmakta, tartışmakta ve bütün bu eylemlere zaman ayırmaktadırlar. Bireylerde bu zihinsel ve davranışsal eylemlerin yapılmasını sağlayan konu ya da olaylar, bu bireylerin gündemini oluşturmaktadır. Bazen küçük bir grubu, bazen bir toplumu, bazen de tüm dünyayı etkisi altına alan 
gündem konuları, bireylerin bu konulara ya da olaylara verdikleri önem sırasına göre kendi gündemlerini oluşturmaktadır.

İşte bu noktada halkın kendi gündemi olarak düşündüğü, esasında medyanın kendi çıkarlarına ve isteklerine uygun konuları, olayları belirleyip, çeşitli sunum tekniklerini kullanmasıyla halkın gündemini oluşturduğunu savunan kuram ön plana çıkmaktadır. Gündem oluşturma/belirleme olarak ifade edilen bu kuram, medyanın kamuoyunun şekillenmesini nasıl etkilediğini açıklayan önemli iletişim kuramlarından birisidir. Kurama göre, medya toplumun önceliğine, neyi bilmesi ve merak etmesi gerektiğine karar vermesi ile suni bilinç oluşturmakta ve oluşturduğu bu bilinç gerçek gündem halini almaktadır (Yegen, 2014, s.25). Medya önemli gördüğü ya da öncelik verdiği konuları, kamunun zihninde de önemli ya da öncelikli konular haline getirmekte (Yüksel, 2007, s.578); böylece kamuoyunun oluşmasını önemli ölçüde etkilemektedir. Gündem sıralamasına giren olayın ait olduğu kategori ya da konu ise, gündem maddesi olarak tanımlanmaktadır (Dearing ve Rogers, 1996, s.2) . Dolayısıyla Cohen'in (1963) de söylediği gibi "medya çoğu zaman insanlara ne düşüneceklerini söylemede başarılı olmayabilir fakat ne hakkında düşüneceklerini söylemede oldukça başarılı" olmaktadır (1963, s.13). Medyanın sahip olduğu en önemli rollerden birisi, insanların doğrudan deneyimlerle öğrenemeyeceği olayları nasıl algılayacağını belirlemesidir (Weaver vd., 1981, s.4). Medya, gündem seçimi ve sunum biçimiyle insanların sosyal gerçekliğini şekillendirmede önemli rol oynamaktadır. Her gün insanların dünyasını onlar adına düşünsel olarak düzenlemektedir (Show ve McCombs, 1977, s.5). Medya tarafından her gün seçilerek kendine özgü sunum biçimiyle hazırlanan içerikler, okuyucularının o gün hangi konuların önemli olduğuna dair algılarını etkilemektedir. $\mathrm{Bu}$ bağlamda medya sahip olduğu bu etki sayesinde okuyucularının (kamunun) düşünme ve tartışma gündemini düzenlemektedir (Atabek, 2012, s.156).

Gündem oluşturma kuramı, tutum değişikliğine bir alternatif olarak kitle iletişim araçlarının toplum üzerinde etki yaratabileceğini vurgulaması açısından önem taşımaktadır. Hatta toplumda oluşabilecek etkinin anlamlı olabileceğine dair göstergeler bulunmakta, medyanın toplumun yüz yüze kaldığı ana sorunlarla ilgili olarak insanların bakış açılarını şekillendirdiğine yönelik kanıtlar görülmektedir (Severin ve Tankard, 1994, s.399). Yüksel (2007), gündem oluşturma yaklaşımında medyanın iletileri aracılığıyla ilk olarak kamuoyunu haberdar etme ve farkına varma işlevini gerçekleştirdiğini, ikinci aşamada ise insanlar daha ayrıntılı bilgi edinme eğilimi gösterdiği için bilişsel düzeyde etkinin söz konusu olduğunu ifade etmektedir. Ardından gündeme yönelik duygusal bir medya etkisinin ortaya çıktığını; bu etki de tutum ve kanaat değişimini sağladığını belirtmektedir. Son olarak medya etkisinin davranış değişikliği üzerine odaklanarak davranışsal düzeyde bir değişim/oluşum gerçekleştirdiğini vurgulamaktadır.

Medya gündem oluşturma sürecinde daha önce geleneksel mecraları kullanırken, artık günümüzde bilgi ve iletişim teknolojilerinin gelişimiyle geleneksel mecraların yanı sıra, hatta bazı durumlarda daha fazla, başta sosyal medya olmak üzere yeni medya ortamlarından faydalanmaktadır. Çünkü sosyal medyanın kullanıcılarına sağladığı olanaklar, çok çeşitli içeriklerin üretilerek geniş kitlelerle paylaşımına olanak vermekte; bu nedenle yoğun kullanım oranı her geçen gün artmaktadır. Ayrıca geleneksel medya ortamından farklı olarak, içeriklerin yapılan paylaşımlar üzerinden kullanıcılarla ve kullanıcıların kendi aralarında etkileşimi gerçekleşmektedir. Üstelik bu paylaşımlar, çok hızlı ve anlık olarak yapılabilmekte; anlık olmasına rağmen yine çok hızlı biçimde geniş bir kitleye yayılabilmektedir. Bütün bu olanaklar sayesinde, herhangi bir konu, kişi ya da durumla ilgili paylaşım, geleneksel mecralardan daha hızlı ve istenilen anda sosyal medya kullanıcılarına ulaşabilmektedir. Ayrıca kullanıcıların birbirini etiketlemesi ya da birbirleriyle kolay mesajlaşma gibi ulaştırma ortamlarını kullanması sayesinde istedikleri içerikleri istedikleri bireylere gönderebilmektedir. $\mathrm{Bu}$ bağlamda herhangi bir kişinin ya da kurumun bir paylaşımı, bir anda insanların dikkatini çekerek sosyal medya ortamında paylaşılmaya ve üzerinde konuşulmaya başlayabilmektedir. Böylece sosyal medyada bir konu, bir anda gündem konusuna dönüşebilmektedir. Artık denilebilir ki; bir kitle iletişim aracı olarak internet, geleneksel medya araçlarıyla benzer biçimde kamuoyunu etkileyebilmekte ve toplumun gündemini belirleyebilmektedir.

Başta sosyal medya olmak üzere birçok farklı internet ortamı bir taraftan gündemin oluşmasını ya da değişmesini sağlarken, bir taraftan da kullanıcıların onlara ulaşan mesajlara yaklaşımını ve 
değerlendirme biçimini etkilemektedir. Sosyal medyanın sunduğu olanaklar, kurum ya da kuruluşlar ile bireysel kullanıcıların gündem belirlemesini, gündem değiştirmesini sağlamakla birlikte gündemin yayılmasına da katkı vermektedir.

Sosyal medyada gündemin çok hızlı oluşabilmesi ve anında büyük kitlelere ulaşabilme olanağına sahip olması, tüketici kitlesine ulaşıp dikkatini çekmekte zorlanan markaların, tüketici gündemine girebilmek ya da orada kalabilmek için sosyal medya ortamında iletişim çalışmaları yapmasını zorunlu kılmıştır. Gündem oluşturma kuramından faydalanarak yaratıcı uygulamaların yapıldığ tanıtım çalışmalarına reklamcılık alanında sıklıkla karşılaşılmaktadır.

Gündem belirlemede anahtar nokta, insanların dikkatini çekmektir. Reklamcılıkta da öncelikli amaç, markalara/ürünlere yönelik hedef kitlenin dikkatini çekmektir. Markalar çeşitli yaratıcı reklam çalışmaları aracılığıyla hedef kitlenin dikkat ve ilgisini toplayarak onların hem kendi gündemlerine hem de tüketiciler olarak kamuoyu gündemine yerleşmek istemektedir. Tüketicilerin gündemine girebilmek için daha önce de belirtildiği gibi markaların yapabileceği iki durum söz konusudur. Bunlardan ilki çok yaratıcı, farklı ve çarpıcı bir reklam tasarımı yaparak reklamın kendisinin gündem haline gelmesidir. İkincisi ise, markanın kamuoyu gündemi içerisinde yer alan konular arasından birini seçerek reklam mesajına dönüştürmesi sonucunda kamuoyunun odak noktasını normal gündem maddesinden markaya çekmesi, böylece marka gündemi haline dönüştürmesidir. Gündem konularının reklam mesajına dönüştürülmesi üzerine kurulu olan ve son dönemlerde kullanım düzeyini oldukça arttıran dikkat çekici reklam uygulamalarının başında gerçek zamanlı reklamlar gelmektedir.

\section{Gündemin Reklam Mesajına Dönüşmüş Hali: Gerçek Zamanlı Reklamlar}

Gerçek zamanlı reklam uygulamaları, markaların gündemi takip ederek anlık gerçek zamanlı bilgilere dayalı marka mesajlarını oluşturduğu; bu mesajıyla da müşterileri ya da takipçileriyle etkileşim kurabilme yeteneğini ifade etmektedir. Gerçek zamanlı bilgi, son dakika haberi, müşteri hareketleri, trend konularla ilgili olabilmektedir (https://www.webolizma.com/gercek-zamanli-pazarlama-nedir/). $\mathrm{Bu}$ tarz tüketicilerin dikkatini, ilgisini çekmiş güncel olaylara/durumlara hızlı ve zamanında yanıt vermeye odaklanan bir stratejinin uygulanması söz konusudur. Bu açıklamalar doğrultusunda gerçek zamanlı reklamlar, gündemde yer eden, konuşulan olayların, markanın ürün/hizmetiyle doğru, yaratıcı bir kurguyla ilişkilendirilmesidir. Esasında gündemin marka gündemine uyarlanmasıyla başlayan, hedef kitleyle gündem üzerinden doğrudan iletişim kuran mesajların gönderilmesini de içeren, anlık ve etkili içeriklerin paylaşım süreci olarak da ifade edilebilmektedir (Şit, 2018, s.1).

Gerçek zamanlı reklamlarda gündem oluşturma kuramının temeli esas alınmakta, tüketicilerin dikkat ve ilgilerini ürün ya da markaya çekerek, ürün ya da markanın özellikleriyle ilgili düşünmeleri için onları mesaja odaklamaya çalışmaktadır. Reklamcıların kampanya ve mesajlarının sadece içinde bulundukları döneme ayak uydurmasına değil, hedef kitlesinin dikkatini çekmek için ilgili konuların avantajlarından da faydalanmaya ihtiyaçları bulunmaktadır (Kerns, 2014, s.14). Bu nedenle gündeme gelebilmek ya da orada kalabilmek için ilgili konunun içerisine kendisini dahil etmesi, avantajları da beraberinde getirmektedir. Bir reklamcı için gündem oluşturma, hedef kitlesinin dikkatini yakalamak için doğru stratejiler geliştirerek reklam tasarımını ve hikayesini doğru, etkileyici biçimde çerçevelemesidir. Özellikle hedef kitlesine marka ya da ürünle ilgili anlatacağı olayın, doğru çerçeve ve içerik içerisinde kurgulanması oldukça önemlidir.

Aynı zamanda reklamcının doğru zamanda doğru yerde, doğru mesajla buluşması da başarılı olmak için gereklidir. Geçmiş dönemde insanların eğilimleri, ilgilendikleri konular, tükettikleri ürünler, markalara bağlılıkları vb uzun süre varlığını korumaktaydı. Uzun süre akılda kaldıkları için konular daha tahmin edilebilir olmaktayd,, dolayısıyla planlı, uzun soluklu reklam planları tasarlanabilmekteydi. Ancak artık çok hızlı yaşanılan günümüzün dijital dünyasında, 24 saat içerisinde birden çok mikro eğilimlere sahip yeni konular yaratılmaktadır (Kerns, 2014, s.14). Bu nedenle markaların, gündemdeki gelişmeleri, tutum ve davranış eğilimlerini, değişiklikleri sıkı sıkıya takip ederek öngörüde bulunmaları gerekmektedir. Bu takipler sonrasında, oyunun dışında kalmamak için gündemi kendisine entegre etmesi gerekmektedir.

Hatta pazarlama ve marka iletişimi alanında birçok noktada olduğu gibi gerçek zamanlı reklamlarda da gündemi ilk kullanan, ilk harekete geçen, ilk cevap veren olmak önem kazanmaktadır. Çünkü kazanan 
markalar, bu ilk adımı atan markalar olmaktadır (Scott, 2010, s.1). Günümüzün iletişim dünyasında bir marka sosyal medyadaki herhangi bir platformda tüketicilerle ne kadar erken iletişim ve etkileşim içerisine girerse, o kadar çok takipçi elde etmekte, tüketicilerle istediği ilişkiyi kurma avantajını elde edebilmektedir. Gerçek zamanlı olarak yeni gelişmeler temelinde başarılı reklam mesajı tasarlandığında, yeni gelişmeyle beraber viral olma ihtimali artmaktadır (Kerns, 2014). Diğer taraftan oluşturulan reklam mesajı gündem konusuyla ne derece bağlantılı ve yaratıcıysa, yayılma potansiyeli o kadar yüksek olmaktadır (Şit, 2018, s.1). Sosyal medya platformlarında tüketicilerle etkileşime girerek yaptıkları zekice, esprili, ironik ve gündemle uyumlu içerikler sayesinde tüketicilerden olumlu tepkiler alabilmektedirler (Kerns, 2014). Örneğin beğendikleri gerçek zamanlı reklamları paylaşmaları, reklamların kamuoyunun gündeminde kalmasını sağlamakta, tüketicilerin kendi aralarında tartışmasını ve reklamın etkisini arttırabilmekte (Hazaparu, 2014, s.331); markaların da tüketicilerin reklamın altına yazdığı yorumlar üzerinden onlarla dialoga geçmesi, böylece onlarla insani bağlar kurabilmesini mümkün k1labilmektedir.

Sosyal medya platformlarında markaların yaptıkları paylaşımlar, onlara sanki bir insanmış algısı oluşturmakta ve kişilik kazandırmaktadır. Dolayısıyla bu algı çerçevesinde markaların gerçek zamanlı olaylara tepki vermeleri, kabul edilebilir görünmektedir. Başka bir ifadeyle sosyal medya kullanıcıları, markaların bu tarz tepki vermelerinden rahatsızlık duymamaktadır. Bu nedenle markalar gerçek zamanlı uygulamalar yapmayı tercih etmektedir. Gerçek zamanlı sosyal katılım, marka farkındalığını güçlendiren, tüketiciler arasında aktif ve görünür olarak marka değeri yaratmakta (Kerns, 2014); markaların akılda kalması, takipçilerin kazanılması ve tüketicilerin satın alma kararlarını etkilemesi açısından çok önemli katkılar sağlamaktadır (Miller, 2015).

Markalar müşteri analizleri, iç görü platformları ve gerçek zamanlı pazarlama araçları sayesinde gerçek zamanlı her türlü bilgiye ulaşabilmektedirler. Özellikle sosyal medya platformlarının sunduğu tüketici bilgileri aracılı̆̆ıla, güncel bilgileri toplayabilmekte, onların hangi gündem konularıyla ilgilendiği bilgisine ulaşabilmekte, böylece tüketicilerin ilgi alanlarına uygun ve ilgilendikleri anda gerçek zamanlı olarak reklam mesajını gönderebilme fırsatı bulabilmektedir. Dolayısıyla tüketicinin ilgisi temelli gündem konusuyla marka mesajını tüketiciyle buluşturduğunda, ürün/hizmetler tüketicilere daha çekici gelmektedir. Memnuniyet ve özel ilgi beklentisi içerisindeki tüketicilere ihtiyaç duydukları anda marka mesajı ulaştığında, satın alma ihtimali artmaktadır. LeadSift'in elde ettiği verilere göre, gerçek zamanlı reklamlar müşteri duyarlılığında \%16'lık artış gerçekleştirmekte, satın alma niyetinde \%14, ilgi alanında \%18'lik bir artış sağlamaktadır. Tüketicilerin markayı dikkate alma olasıllğının ise \%22 olduğu belirlenmiştir (https://www.webolizma.com/gercek-zamanlipazarlama-nedir/).

\section{Başarılı Gerçek Zamanlı Reklamların Özellikleri ve Yapılan Araştırmalar}

Gerçek zamanlı reklamların bahsedilen avantajları nedeniyle birçok marka bu reklam uygulamalarını kullanmaktadır. Çünkü her marka göz önünde olmak, yeni eğilimlerin bir parçası olarak rakiplerinden geri kalmamak, hatta öne geçmek istemektedir. Ancak başarıyı elde edebilmek için doğru adımların atılması gerekmektedir. Tüm stratejik plan ve uygulamalarda olduğu gibi, bu reklam uygulamasının da sahip olması gereken birtakım özellikler bulunmaktadır. Markaların gerçek zamanlı reklam tasarımı yaparken bu özelliklere dikkat ederek yapmaları gerekmektedir.

Gerçek zamanlı reklamların yapılma amaçlarından birisi, tüketicilerin dikkatini çekip viral olmasını sağlamaları için başkalarını ve ilgili kelimeleri etiketleyerek, tekrar tweet ederek, beğenerek vb reklamın yayılmasını sağlamaktır. Bunun olması için trendi değil, tüketicilerin ilgisini çeken şeyleri konu etmek gerekmektedir (Dieguez, 2015). Başka bir ifadeyle tüketicinin ilgisini çeken gündem konularını temel alan anlık çalışmalar yapılması, beklenen tepkilerin oluşmasını sağlayabilmektedir. Takipçiler her zaman ilgilerini çeken şeyin arayışı içerisindedir. Eğer markalar sosyal medyanın değişen doğasına ayak uydurarak gündemle ilgili ve hedef kitlenin hoşlanacağı bir reklam tasarımı gerçekleştirirse, tüketici kitlesi başkalarının da bu yaratıcı uygulamayı görmesini isteyecek, viral olmasını sağlayarak birçok kişiye ulaşılmış olacaktır. Bu durum yeni takipçiler, daha büyük çaplı etkileşimler ve hatta yeni müşterilerin gelmesi anlamına gelmektedir. 
Gerçek zamanlı reklamlar, gündemdeki konunun konuşulup tartışılması ve birçok kişi tarafından takip edilmesine; bu durum zirve noktaya ulaştığında ise markaların bu etkileşim ortamına katılmasına dayanmaktadır. $\mathrm{Bu}$ gündem konusunun etkileşimi, en tepeye ulaştıktan sonra popülerliği düşüşe geçmekte ve gündemdeki üstünlüğünü kaybederek yerini başka bir gündem konusuna bırakmaktadır. Özellikle sosyal medya ortamında paylaşım gerçekleştiği için, gündem değişimi çok hızlı meydana gelmektedir. Bu nedenle markaların istediği iletişim ve etkileşimi gerçekleştirmek için gündemi anlık takip etmesi ve hızlı tepki göstermesi gerekmektedir (Macy ve Thompson, 2011,s. 39). Aksi takdirde kimsenin dikkate almadığı bir uygulama olacaktır.

Etkileyici bir gerçek zamanlı reklam uygulaması, gündeme göre ve anlık özellik taşıma üzerine olmasına rağmen, hiçbir zaman herhangi bir stratejiye bağlı olmadan, keyfi ya da rastgele biçimde yapılamamaktadır (Clow ve Baack, 2006, s.265). Özellikle gündem temelinde şekillendiği için mutlaka bir gerekçesi, bağı ve yapılma hedefi olmalıdır. Stratejik alt yapı olmadan tasarlanıp paylaşılmış içerikler, başarının yerine markayı çok olumsuz etkileyebilecek bir kriz yaşamasına neden olabilmektedir. Aynı zamanda gerçek zamanlı reklamlar; gerçek zaman, yani "o an", prensibine dayalı olarak geliştirilip uygulansa bile, bu reklamın her zaman gerçek zamanlı yapılması anlamına gelmemektedir. Başka bir ifadeyle reklam içeriği gerçek zamanlı olarak yayınlansa da tasarımının planlanma ve uygulanma süreci daha önce yapılabilmektedir (O'connor, 2015). Örneğin özel günlere ait tarihler bellidir ve değişmemektedir, dolayısıyla özellikle tüketiciler açısından çok önemsenen özel günlerin gündemi, daha önce reklam mesajına dönüştürülerek özel günün tarihi geldiğinde paylaşılabilmektedir. Örneğin bir ünlünün ne zaman gaf yapıp gündeme yerleşeceğini bilmek mümkün değildir, ancak çok ilgi gösterilen bir filmin gösterime giriş tarihi bellidir. Dolayısıyla gerçekleşme zamanı gelmeden, ancak gerçekleşmesi belli ve kesin olan, gündemi yüksek olan tarihlere yönelik gerçek zamanlı bir tasarım yapılması mümkün olabilmektedir.

Kerns (2014), konuların işlenmesi bakımından gerçek zamanlı reklam konularının içeriğini bilinen ve bilinmeyen olarak ikiye ayırmıştır: Konusu bilinen gerçek zamanlı reklamlarda, planlı olarak tarihi ve konusu önceden bilinen, gündemde yer alacak bir olayla bağlantılı reklam içeriği hazırlanmakta ve olayın tarihi geldiğinde bu içerik paylaşılarak hedef kitlelerle iletişim kurulmaktadır. Spor müsabakaları, ödül törenleri, beklenen doğa ya da gökyüzü olayları, filmin gösterime girmesi gibi takvimde gerçekleşeceği günü belli olan ve önemli gün olarak belirtilen günler, gerçek zamanlı reklamların yoğun olarak kullanıldığı gündemlerdir (Kerns, 2014, s.89). Konusu bilinmeyen gerçek zamanlı reklamlar ise, gerçekleşeceği daha önceden bilinmeyen, ama gündeme yerleşerek zirve yapan, insanların üzerinde yoğun biçimde konuştuğu bir gündem konusu marka mesajına uyarlanarak yapılmaktadır. Gündem konusunun ne zaman olacağı bilinmediği için, plansız, spontone olarak ve mümkün olduğunca hızlı biçimde gündem konusunun, reklam mesajına dönüştürülmesi oldukça önem taşımaktadır. Başarılı uygulandığı takdirde rakiplere büyük fark atılabileceği gibi, yanlış uygulandığında ise çok büyük, olumsuz tüketici tepkilerine maruz kalma gibi büyük riskler taşımaktadır( Scott, 2010, s.126).

Daha önce de belirtildiği gibi, gerçek zamanlı reklamlar ister planlı isterse plansız bir biçimde tasarlansın, mutlaka tüketicilerin ihtiyaç duyduğu şeyi yansıtan, tüketicinin mesajda aktarılan bağlantıyı rahatlıkla algılayabileceği, ürünle ve gündemle uyumlu, doğru zamanda yapıldığında etkili bir strateji haline gelmektedir. Dieguez (2015) gerçek zamanlı reklamların gündemi firsata çevirebilmesi ve beklenen başarıyı sağlamasında, üç kavramın çok önemli olduğunu vurgulamaktadır: İlki tasarlanan reklamın, işletme, marka/ürün/hizmetle ilgili olmasıdır. Hiçbir reklam çalışmasında olmamas1 gerektiği gibi, kesinlikle reklamı oluşturan hiçbir öğenin marka, işletme ve ürün/hizmetin önüne geçmemesi gerekmektedir. Esas olan sadece reklamın konuşulması değil, reklam aracılığıyla marka, ürünün ya da işletmenin konuşulmasıdır. Ayrıca hem gündem hem reklam mesajı hem yazılı metin, hem de görsel içeriğin, mutlaka marka kimliğiyle uyumlu olması da önem taşımaktadır. İkinci kavram, hazırlanan içeriğin mutlaka hedef kitleyle ilgili olmasıdır. Reklam içeriği hedef kitleyi yansıtan, onun ilgi alanına girebilecek ve ihtiyaçlarıyla ilgili mesajlar içeriğine sahip nitelikte olmalıdır. Son önemli kavram ise; tasarlandığ 1 ve hedef kitleyle buluştuğu zamanın, yaşanılan anla ilgili olmasıdır. Çok kısıtlı bir zamanda, anlık tepkilerden yola çıkarak hızlı bir biçimde tasarlanıp doğru zamanda doğru içeriğin doğru hedef kitleyle buluşması gerekmektedir. 
Markaların sosyal medyada paylaştıkları gerçek zamanlı reklamlar, görsel ve/veya yazılı bileşenlerden oluşmaktadır. Görsel bileşen; fotoğraf, gif, video vb ve bunların içinde yer alan interaktivite unsurları (tag, lokasyon vb) ifade etmektedir. Yazılı bileşen ise, görselin üzerinde yer alan yazılı metin ve interaktivite unsurlardan (hashtag, mention vb) oluşmaktadır. Bu çalışmada hem görsel hem de yazılı içerikler dikkate alınarak incelenmiştir. İşte gerçek zamanlı reklamların görsel ve/veya yazılı öğelerinin gündem konusuyla, ürün özelliğiyle uyumlu olması ve bu özellikleri yansıtması, tüketici ihtiyacıyla gündem konusunun birleşiminden oluşması çok önemlidir. Çünkü reklamın yapılma amacı; ürün/hizmetin ya da markanın göz önüne gelerek duyulması, tercih edilmesi ve tüketiciyle bağ kurulmasıdır. Dolayısıyla reklam mesajıyla gündem birleşiminin doğal, samimi olması; zorlama hissi oluşturmaması gerekmektedir. Ancak bu şekilde markaya yönelik beklenen ilginin ve viralin elde edilmesi mümkün olabilmektedir.

Ülkemizde olduğu gibi tüm dünyada gerçek zamanlı reklamlar, markalar tarafindan çok tercih edilen uygulamalardır. Ancak yapılan tüm gerçek zamanlı reklamların aynı ya da beklenen etkiyi yaratmadığı görülmektedir. Çünkü "herkes yapıyor biz de geri kalmayıp yapalım” mantığıyla hareket edildiği görülmektedir. Oysaki sırf yapmış olmak için değil, gündem konusunu marka mesajıyla zekice, yaratıcı ve etkileyici biçimde yeniden yorumlamak başarıyı getirebilmektedir. Gündem konusu, ürün özellikleri, tüketici ihtiyacı arasındaki uyum oldukça önem kazanmaktadır. Örneğin; 2018 Dünya Kupası'nda Hırvatistan milli takımında yer alan Beşiktaşlı futbolcu Domagoj Vida'nın maçlarda gösterdiği başarılı performans nedeniyle değerinin artması gündeme yerleşmiş; Koçtaş da bu gündemin popülaritesinden faydalanmıştır. Koçtaş sattığı vida ürününü reklam görseline koyarak "Biz de hala 2.29 TL" metniyle futbolcu Vida'nın yükselen fiyatına gönderme yapmak için kendi fiyatının uygunluğunu vurgulayıp, oldukça başarılı bir gerçek zamanlı reklam çalışması yapmıştır (https://twitter.com/Koctas/status/1017453544088244224?ref_src=twsrc\%5Etfw\%7Ctwcamp\%5Etwe etembed\%7Ctwterm\%5E1017453544088244224\&ref_url=https\%3A\%2F\%2Fmediacat.com\%2Fkocta stan-vida-yorumu $\% 2 \mathrm{~F}$ )

Markaların, yaptıkları gerçek zamanlı reklamları birçok sosyal medya platformunda paylaştıkları görülmektedir. Farklı kullanıcı profiline sahip herhangi bir sosyal medya platformu için gerçek zamanlı reklamlar tasarlanıp paylaşılabilmektedir. Bu noktada dikkat edilmesi gereken şey; markaların bu reklamı tasarlarken hem mesaj içeriğinin hem de bağlantılı paylaşımlarını, hedef kitlelerine verdikleri cevapları, reklamın yer alacağı sosyal medya platformunun özelliklerine uygun olarak yapması gerekmektedir (Kerns, 2014, s.6). Her sosyal medya platformunun dinamikleri ve kullanıc1 kitlesi de dahil, özellikleri farklıdır. Bu nedenle platformun kullanıcı kitlesinin özellikleri ve platformun özellikleri temelinde tasarımın yapılması başarı için önem kazanmaktadır.

Diğer taraftan bu reklam uygulaması için en uygun sosyal medya platformu Twitter'dır. Çünkü Twitter gerçek zamanlı paylaşım prensibine sahiptir. Bu platformda etkileşim, anlık olarak gerçekleşmektedir. Gerçek zamanlı reklamlar da markaların anlık içerik üretimi ve tüketicilerle etkileşim içerisinde olma prensibine dayanmaktadır. Ayrıca markalar gündem konularını yakalayabilmek için Twitter' daki trend topik konularını takip ederek kendileri ve tüketicileri için en uygun ve doğru gündem konusunu hemen belirleyebilme şansına sahiptir.

Sosyal medya ve gerçek zamanlı reklamlarla ilgili önemli bir diğer konu, tasarlanan reklamın paylaşılabilir olmasıdır. Bu reklam uygulamasında amaca ulaşabilmek için öncelikle yapılması gereken, görünürlüğü artırmak ve etkileşimi gerçekleştirmektir (Concannon, 2018). Bu nedenle reklam, viral olmasını sağlayabilecek ve kolaylıkla paylaşılabilecek tasarım özelliklerine sahip olmalıdır. Örneğin etiketlenen kelime gündem konusuyla uygun, kısa ve dikkat çekici olmalıdır. Ya da reklamın dakikalarca süren bir video olmaması gerekmektedir.

Yeni bir uygulama olması nedeniyle gerçek zamanlı pazarlama perspektifinden gerçek zamanlı reklamlarla ilgili literatürde az sayıda çalışmaya rastlanmıştır. Reklamların izlenme düzeyi, mecralarda yayınlanma sıklıkları, izleyicilerin reklama ve markalara yönelik tutumu, reklam içeriklerinin izleyenlerin gündemine konu olma derecesi gibi noktalarla özel günleri konu alan reklamların gündem oluşturmadaki rolü incelenmiş (Şahin ve Şentürk, 2018); geleneksel ve sosyal medyadaki gerçek zamanlı reklamların marka üzerindeki etkinliği ve çekiciliği araştırılarak bu reklamların tüketiciler tarafından nasıl algılandığı analiz edilmiş (Hakansson ve Bengtsson, 2015); eski bir filmin güncel 
versiyonunun gösterime girmesini konu alan gerçek zamanlı reklamların kullanımı incelenmiş (Yılmaz, 2018); reklamda gündem yönetimi çerçevesinde ele alınan bir reklam örneğinin beğeni, paylaşım, yorum, görüntüleme kıstasları doğrultusunda kendisinden beklenen etkileşimi sağlayıp sağlamadığı araştırılmış (Demir, 2017); yüksek tüketici etkileşimi sağlamak için reklam içeriğinin sahip olması gereken özellikler belirlenmiştir (Bazarc1 ve Mutlu, 2017; Eralp, 2018).

Sonuç olarak gerçek zamanlı reklamlar, insanların üzerinde odaklanıp konuştuğu gündem konularının popülerliğinden faydalanarak konu yerine markanın gündeme gelmesi için yapılan, birçok avantaja sahip etkileyici reklam uygulamasıdır. Böylece hedef kitleleriyle etkileşim içerisine girerek tüketicilerle bağ kurmaktan olumlu tutum oluşturmaya, ardından da satışı gerçekleştirmeye kadar birçok iletişim hedefine ulaşabilmektedir. Yeni dijital pazarlama iletişimi stratejilerinden birisi olan gerçek zamanlı içeriklerde aynı gündem konusu, çok farklı ürün kategorilerinde bulunan markalar tarafından yoğun düzeyde kullanılabilmektedir. Bu bağlamda tüketicilerle sosyal medya ortamında paylaşılan gerçek zamanlı reklamların genel kullanım durumlarını ortaya koymak ve doğru yapılıp yapılmadığını belirlemek önem kazanmaktadır. Çünkü markalar daha önce de belirtildiği gibi bazı iletişim hedeflerine ulaşabilmek için bu reklam uygulamalarını kullanmaktadır. Ürün kategorisi ne olursa olsun kitlenin dikkatini markaya odaklamak esastır. Diğer taraftan gerçek zamanlı reklamlar ancak doğru ve başarılı yapıldığı takdirde, gündemin çekiciliğinden faydalanarak marka gündemi oluşturmak ve ağızdan ağıza iletişim yoluyla istenilen hedef kitlelere ulaşmak mümkün olabilmektedir.

\section{AMAÇ}

Bu çalışmanın amacı; markaların Twitter'da paylaştıkları gerçek zamanlı reklam uygulamalarının temel bileşenlerini ortaya koyarak, uygulamanın var olma amacına ve dayandığı kurama uygun olarak kullanılıp kullanılmadığını; reklamın mesaj içeriğiyle birlikte temel bileşenleri ve gündem konusu arasında uyum olup olmadığını belirlemektir.

$\mathrm{Bu}$ doğrultuda araştırma soruları aşağıdaki gibi geliştirilmiştir:

Araştırma sorusu 1: Markaların gerçek zamanlı reklam uygulamalarına yönelik genel kullanım durumu nasildir?

1.1. Markalar gerçek zamanlı reklamları hangi stratejik amaçları gerçekleştirmek için kullanmaktadır?

1.2. Gerçek zamanlı reklamlarda kullanılan içerik öğeleri nelerdir?

1.3. Bu reklam uygulamaları ürün kategorilerine göre nasıl bir kullanım durumuna sahiptir?

1.4. Markaların gerçek zamanlı reklamlarda kullandıkları görsel ve metinsel unsurların özellikleri nelerdir?

Araştırma sorusu 2: Markalar ve yaptıkları gerçek zamanlı reklam uygulamaları arasındaki uyum durumu nasildir?

2.1. Gerçek zamanlı reklamlarda yararlanılan gündem konusuyla ürün arasında nasıl bir uyum bulunmaktadır?

2.2. Bu reklam uygulamalarında yararlanılan gündem konusuyla reklamda verilen mesaj arasındaki uyum durumu nasildır?

2.3. Gerçek zamanlı reklamlarda yer alan görsel içerikle yararlanılan gündem konusu arasında nasıl bir uyum bulunmaktadır?

2.4. Gerçek zamanlı reklamlarda yer alan metin içeriğiyle yararlanılan gündem konusu arasında nasıl bir uyum vardir?

\section{YÖNTEM}

Araştırma amacı doğrultusunda istenen bulgulara ulaşmak için nitel araştırma yöntemleri arasında bulunan içerik analizi yöntemi kullanılmıştır. İçerik analizi her türlü görsel, sözlü ya da yazılı öğelerin toplanarak analiz edilmesi olarak tanımlanmaktadır (Neuman, 2009, s.466). Birçok sosyal bilimler alanında olduğu gibi iletişim alanında da çok sık faydalanılan içerik analizinde, verilerin temalar ve 
kodlar yardımıyla yorumlanabilir hale dönüştürülmesi amaçlanmaktadır (Krippendorf, 2004, s.7). Bu araştırmada da markaların Twitter'da yayınladıkları gerçek zamanlı reklamlara yönelik içerik analizi yöntemi uygulanmıştır.

\section{Örneklem}

31 Mart 2015'te tüm ülkede yaşanılan ve oldukça uzun süren elektrik kesintisi, üzerinde çok konuşularak gündemin ilk sırasına yerleşmişti. Markalar da, herkesin konuştuğu ve odak noktasına aldığı bu gündem konusundan faydalanmak istemiştir. Bu araştırma kapsamında, yaşanılan elektrik kesintisi çıkış noktası yapılarak markalar tarafindan Twitter'da paylaşılan 70 adet gerçek zamanlı reklam uygulaması incelenmiştir. Bu reklamların seçilme nedeni, o dönemde en çok konuşulan aynı gündem konusundan yararlanmalarıdır.

Örneklemi oluşturmak için amaca dayalı örneklem yöntemi seçilmiştir. 70 adet gerçek zamanlı reklama içerik analizi uygulanmıştır. Araştırmanın analiz birimi, elektrik kesintisini konu alan gerçek zamanlı reklamların her birisidir.

\section{Kodlama Formu Ve Verilerin Toplanmasi}

$\mathrm{Bu}$ çalışmada kullanılan kodlama formu literatüre, araştırma amacına ve sorularına bağlı kalarak hazırlanmıştır. Paylaşımın öğelerini ve görsel öğelerin türüne ait kodlar Elden ve Özdem'in (2015); görsel içerikte karakter ve nesne kullanımına ait kodlar Bazarcı'nın (2017); stratejik amaca yönelik kodlar Türkden'in (2013); görsel içerikte metin kullanımıyla ilgili kodlar Çekiç Akyol'un (2011); ürün/hizmet bilgisi, etiket kullanımı, görsel içerikte logo kullanımına ait kodlar ise Üstündağ'ın (2018) çalışmalarından alınmıştır. Ancak bazı kodlar, pilot çalışma sonrasında revize edilerek bu çalışmaya uyarlanmıştır. Gündem konusu ve diğer değişkenlerle arasındaki uyumla ilgili kodlar, araştırmacının kendisi tarafından hazırlanmıştır.

Ana çalışmaya dahil edilmeyen 10 gerçek zamanlı reklam uygulaması üzerinden pilot çalışma yapılmışıır. Hazırlanan kodlama formu, araştırmacının kendisi tarafından farklı zamanlarda kullanılarak veriler elde edilmiştir. Pilot çalışma sonunda sorun yaşanan soru ve kategoriler, tekrar gözden geçirilmiş, gerekli düzeltme ve değişiklikler yapılarak formun son haline ulaşılmıştır. Kodlama formuna Kappa güvenirlik analizi yapılmış ve \%86 güvenirlik oranına sahip olduğu belirlenmiştir. Bu oran, Landis ve Koch (1977) tarafından önemli uyum düzeyi olarak kabul edilmektedir. SPSS programı aracılığıyla veriler analiz edilerek araştırma bulgularına ulaşılmıştır.

\section{BULGULAR}

Araştırmanın bulgular bölümünde öncelikle, markaların gerçek zamanlı reklamlara yönelik genel kullanım durumları ele alınmıştır. Son aşamada ise markaların bu reklam uygulamalarını tasarlarken kullandıkları gündem konusuyla reklamdaki ürün, reklam mesajı, görsel ve metin içerikleri arasındaki uyumluluk durumuna değinilmiştir. Elde edilen bulgular aşağıda yer almaktadır.

\section{Markaların gerçek zamanlı reklamlara yönelik genel kullanım durumları}

$\mathrm{Bu}$ bölümde markaların gerçek zamanlı reklamlara yönelik genel kullanım durumları; paylaşımın stratejik amacı, ürün kategorileri açısından bu reklam uygulamalarının kullanım oranları, kullanılan içerik öğeleri, reklamlarda kullanılan görsel ve metinsel içeriğin özellikleri perspektifinden ele alınmıştır.

\subsection{Markaların gerçek zamanlı reklamları kullanmasına yönelik stratejik amaçları}

Çalışmada ilk ele alınan konu, markaların hangi stratejik amaçlara ulaşmak için gerçek zamanlı reklamlardan faydalandığıdır. Tablo 1, bu reklam uygulamalarının kullanılma amacına dair elde edilen bulguları göstermektedir. İncelenen markaların \%34,2'sinin marka imajını desteklemek, \%28,6'sının ürüne ait bilgi vermek, \%10'unun ise tüketiciyle bağ kurmak ya da ürünü satın alması için doğrudan yönlendirmek amacıyla gerçek zamanlı reklamları kullandıkları belirlenmiştir. Ayrıca \%5,7 markanın müşteri hizmetleri konusunda bilgi vermek/yönlendirmek ya da gündemi oluşturan konuya yönelik tepkisiz kalmamak için, \%3'nün tüketicilerle etkileşim kurmak ve \%1'inin ise hali hazırda devam eden reklam kampanyalarına destek olmak için bu uygulamalardan faydalandıkları tespit edilmiştir. Elde edilen bulgular, Araştırma Sorusu 1.a'yı cevaplamaktadır. 
Tablo 1. Markaların GZR'ları kullanmasına yönelik stratejik amaçları

\begin{tabular}{|l|c|c|}
\hline GZR'ın stratejik kullanılma amacı & Frekans & Yüzde (\%) \\
\hline Marka imajı destekleme & 24 & 34,2 \\
\hline Ürün/hizmet bilgisi aktarma & 20 & 28,6 \\
\hline Tüketiciyle bağ kurma & 7 & 10 \\
\hline Ürün satışının gerçekleşmesi & 7 & 10 \\
\hline $\begin{array}{l}\text { Müşteri hizmetleri konusunda bilgi } \\
\text { verme/yönlendirme }\end{array}$ & 4 & 5,7 \\
\hline $\begin{array}{l}\text { Gündem konusuyla ilgili tepki } \\
\text { gösterme }\end{array}$ & 4 & 5,7 \\
\hline Tüketicilerle etkileşim kurma & 3 & 4,3 \\
\hline $\begin{array}{l}\text { Mevcut reklam kampanyasını } \\
\text { destekleme }\end{array}$ & 1 & 1,4 \\
\hline Toplam & $\mathbf{1 0 0}$ & $\mathbf{1 0 0}$ \\
\hline
\end{tabular}

\subsection{Markaların paylaştıkları gerçek zamanlı reklamların içerik öğeleri}

Tablo 2'de markaların aynı gündem konusuyla ilgili paylaştıkları gerçek zamanlı reklamlarının içerik öğeleri görülmektedir. Markaların \%51,4'ü bu reklam uygulamasında hem görsel hem de yazılı içeriği bir arada kullanmayı tercih ederken, \%47,1'i sadece yazılı içeriği, \%1,4’ü ise yalnızca görsel içeriği kullanmıştır. Elde edilen bulgular Araştırma Sorusu 1.b'nin cevabını oluşturmaktadır.

Tablo 2. Paylaşılan gerçek zamanlı reklamların içerik öğeleri

\begin{tabular}{|l|c|c|}
\hline Gerçek zamanlı reklamların içerik öğeleri & Frekans & $\begin{array}{c}\text { Yüzde } \\
(\mathbf{\%})\end{array}$ \\
\hline Görsel ve yazının birlikte kullanımı & 36 & 51,4 \\
\hline Yazılı içerik & 33 & 47,1 \\
\hline Görsel içerik & 1 & 1,4 \\
\hline Toplam & $\mathbf{7 0}$ & $\mathbf{1 0 0}$ \\
\hline
\end{tabular}

\subsection{Gerçek zamanlı reklam uygulamalarının kullanıldığı ürün kategorileri}

Çalışmada gerçek zamanlı reklam uygulamaları, aynı gündem konusunu ele alan markaların yer aldıkları ürün kategorileri açısından da incelenmiştir. Bunun yapılma amacı, gerçek zamanlı reklam uygularının en çok hangi ürün kategorileri tarafından kullanıldığını belirlemektir. $\mathrm{Bu}$ reklam uygulamasını kullanmayı tercih eden ürün kategorilerine ait bulgular, Tablo 3'te yer almaktadır.

Tablo 3. Gerçek zamanlı reklamları kullanan ürün kategorileri

\begin{tabular}{|l|c|c|}
\hline Gerçek zamanlı reklamları kullanan ürün kategorileri & Frekans & Yüzde (\%) \\
\hline Gıda (yiyecek, içecek, sakız,şekerleme) & 27 & 38,6 \\
\hline Online/Fiziki perakende mağaza markaları & 9 & 12,8 \\
\hline Otomotiv/Yan ürünler (otomobil, petrol ürünleri, parçalar vb) & 6 & 8,6 \\
\hline Bilgi /íletişim teknolojileri (Bilgisayar, cep telefonu vb) & 5 & 7,1 \\
\hline Kişisel bakım/Kozmetik & 4 & 5,7 \\
\hline Sağlık (sağlı hizmetleri, kondom vb) & 4 & 5,7 \\
\hline Beyaz eşya/dayanıklı ev tüketimi & 4 & 5,7 \\
\hline $\begin{array}{l}\text { Finansal hizmet (sigortacılık hizmetleri, bankacılık hizmetleri, bireysel } \\
\text { emeklilik vb) }\end{array}$ & 3 & 4,3 \\
\hline Temizlik malzemeleri (deterjanlar, bebek bezleri vb) & 3 & 4,3 \\
\hline Eğlence/Medya (Dergi, gazete, tatil, müzik, oyun, dijital TV programları vb) & 2 & 2,9 \\
\hline Tekstil/Aksesuar (Kıyafet, ayakkabı, aksesuar vb) & 1 & 1,4 \\
\hline Eğitim & 1 & 1,4 \\
\hline Diğer & 1 & 1,4 \\
\hline Mobilya & 0 & 0 \\
\hline Toplam & $\mathbf{1 0 0}$ & $\mathbf{1 0 0}$ \\
\hline
\end{tabular}


Aynı gündem konusundan faydalanarak gerçek zamanlı reklam çalışması yapan markaların içinde bulundukları ürün kategorilerine bakıldığında, en fazla\%38,6 ile gıdanın, ikinci olarak \%12,8 ile online ve fiziki perakende mağazalarının, üçüncü olarak ise \%8,6 ile otomotiv kategorisinin olduğu görülmektedir. İlk üç kategoriyi; \%7,1 ile bilgi/iletişim teknolojileri, \%5,7 ile kişisel bakım, sağlık ve beyaz eşya kategorileri, \%4,3 ile finansal hizmetler ve temizlik malzemeleri kategorileri takip etmektedir. Elde edilen bulgular Araştırma Sorusu 1.c'nin cevabını oluşturmaktadır.

\subsection{Gerçek zamanlı reklamlarda kullanılan görsel ve yazılı içerik unsurlarının özellikleri}

Bu başlık altında gerçek zamanlı reklamların görsel ve yazılı metin özellikleri, ürün kategorileri, görsel ve yazılı içeriği oluşturan öğeler açısından ayrı ayrı değerlendirilmiştir. Elde edilen bulgular Araştırma sorusu 1.d'nin cevabını oluşturmaktadır.

\subsection{1. Ürün kategorilerine göre gerçek zamanlı reklam uygulamalarında kullanılan içerik öğelerinin kullanım durumu}

Çalışma kapsamında ele alınan noktalardan birisi, paylaşılan gerçek zamanlı reklam uygulamalarında yer verilen içerik öğelerinin ürün kategorileri arasında farkl1lık gösterip göstermediği, kategorilere göre en çok hangi içerik öğesinin kullanımının ön plana çıktı̆̆ıdır. Tablo 4 'ten de görüldüğü üzere, genel olarak bütün ürün kategorilerine ait bu reklam içeriklerinin \%54,1'inde hem görsel hem de yazılı içerik birlikte kullanılmış, \%44,4'ünde sadece yazıya yer verilmiş, \%1.4'ünde ise tek başına görsel kullanılmıştır. Ayrıntılara bakıldığında; reklamlarında görsel içeriğe yer veren $(\% 1,4)$ tek bir kategorinin bulunduğu, o kategorinin de sağlık kategorisi olduğu görülmektedir. Diğer taraftan içeriklerinde yazılı metin kullanan kategorilerin, gıda $(\% 22,9)$, online/fiziki perakende mağazaları $(\% 5,7)$, kişisel bakım ile finansal hizmet $(\% 4,3)$, otomotiv ile temizlik malzemeleri $(\% 2,9)$ ve bilgi/iletişim teknolojileri $(\% 1,4)$ kategorileri olduğu tespit edilmiştir. Reklamlarında hem görsel hem de yazıyı bir arada kullanan kategoriler ise yine sırasıyla, gıda $(15,7)$, online/fiziki perakende mağazaları $(\% 7,1)$, bilgi/iletişim teknolojileri, otomotiv ile beyaz eşya $(\% 5,7)$, sağlık $(\% 4,3)$, eğlence/medya $(\% 2,9)$, kişisel bakım, tekstil/aksesuar ve eğitim $(\% 1,4)$ kategorileri olarak belirlenmiştir.

Kategorilerle ilgili alt ayrıntılı bulgular ise şu şekildedir: Gıda kategorisindeki reklamlarda görsel içerikler hiç kullanılmazken, içeriklerde en fazla yazıya $(\% 22,9)$, ardından görsel ve yazılı metnin bir arada kullanımına $(\% 15,7)$ yer verilmiştir. Online/fiziki perakende mağazalar kategorisinde, yine görsel içerik kullanılmamış, bu kategoriye ait reklamların \%7,1'inde görsel ve yazı birlikte kullanılmış, \%5,7'inde yalnızca yazılı içerik kullanılmıştır. Otomotiv kategorisindeki reklamlarda görsel içeriğe rastlanmazken, \%5,7 oranında görsel ve yazının bir arada kullanıldığı içerik, \%2,9 oranında ise sadece yazılı içerik bulunmuştur. Benzer şekilde bilgi/iletişim teknolojileri kategorisinde, görsel içerik kullanılmamış, görsel içerik yerine markaların \%5,7'si görsel ve yazılı metni bir arada kullanmayı, \%1,4'ü sadece yazılı içeriği kullanmayı tercih etmiştir. Kişisel bakım kategorisinde, yine birçok kategoride olduğu gibi görsel içerik kullanılmamış, \%4,3'ünde yazılı içeriğe, \%1,4'ünde ise hem görsel hem de metne birlikte yer verilmiştir. Benzer şekilde metne daha fazla $(\% 2,9)$ yer veren temizlik kategorisindeki reklamlarda, görsel içeriğe rastlanmamış, hem görsel hem de yazının bir arada kullanıldığı içeriğin ise \%1,4 olduğu görülmüştür. Sadece görsel ya da yazılı kullanmak yerine, yazılı ve görsel metni bir arada kullanan kategoriler ise beyaz eşya $(\% 5,7)$, eğlence/medya $(\% 2,9)$, tekstil/aksesuar $(\% 1,4)$, eğitim $(\% 1,4)$ olarak belirlenmiştir. Diğer taraftan sadece yazılı içerik yerine, görsel ve yazıyı birlikte kullanmanın $(\% 4,3)$ yanı sıra sadece görsel içeriğe $(\% 1,4)$ yer veren tek kategorinin sağlık olduğu tespit edilmiştir. Son olarak reklamlarında sadece yazılı içeriğe yer veren $(\% 4,3)$ tek kategorinin ise finansal hizmet kategorisinin olduğu görülmüştür. 
Tablo 4. Ürün Kategorilerine göre gerçek zamanlı reklamlarda kullanılan içerik öğelerinin kullanım durumu

\begin{tabular}{|c|c|c|c|c|}
\hline \multirow{2}{*}{$\begin{array}{llr}\text { Gerçek zamanlı reklamları } \\
\text { kullanan markaların ürün } \\
\text { kategorileri }\end{array}$} & \multicolumn{3}{|c|}{ İçerik öğesi } & \multirow[t]{2}{*}{ Toplam (\%) } \\
\hline & Görsel içerik (\%) & Yazılı içerik (\%) & $\begin{array}{c}\text { Görsel ve } \\
\text { yazılı içerik } \\
\text { birlikte }(\%)\end{array}$ & \\
\hline Gida & 0 & $22,9(16)$ & $15,7(11)$ & $38,6(27)$ \\
\hline Online/Fiziki perakende mağaza & 0 & $5,7(4)$ & $7,1(5)$ & $12,9(9)$ \\
\hline Otomotiv/Yan ürünler & 0 & $2,9(2)$ & $5,7(4)$ & $8,6(6)$ \\
\hline Bilgi /İletişim teknolojileri & 0 & $1,4(1)$ & $5,7(4)$ & $7,1(5)$ \\
\hline Kişisel bakım/Kozmetik & 0 & $4,3(3)$ & $1,4(1)$ & $5,7(4)$ \\
\hline Sağlık & $1,4(1)$ & 0 & $4,3(3)$ & $5,7(4)$ \\
\hline Beyaz eşya/dayanıklı ev tüketimi & 0 & 0 & $5,7(4)$ & $5,7(4)$ \\
\hline Finansal hizmet & 0 & $4,3(3)$ & 0 & $4,3(3)$ \\
\hline Temizlik malzemeleri & 0 & $2,9(2)$ & $1,4(1)$ & $4,3(3)$ \\
\hline Eğlence/Medya & 0 & 0 & $2,9(2)$ & $2,9(2)$ \\
\hline Tekstil/Aksesuar & 0 & 0 & $1,4(1)$ & $1,4(1)$ \\
\hline Eğitim & 0 & 0 & $1,4(1)$ & $1,4(1)$ \\
\hline Diğer & 0 & 0 & $1,4(1)$ & $1,4(1)$ \\
\hline Mobilya & 0 & 0 & 0 & 0 \\
\hline Toplam & 1.4 & 44,4 & 54,1 & 100 \\
\hline
\end{tabular}

\subsubsection{Gerçek zamanlı reklam uygulamalarında kullanılan görsel unsur özellikleri}

$\mathrm{Bu}$ başlık altında markalar tarafından aynı gündem konusu üzerinden paylaşılan gerçek zamanlı reklamlara ait görsel içerik unsurları; görsel içeriğin türü, içerikte kullanılan öğelerin durumu, görsel içerisinde logonun ve metnin kullanımı açısından ele alınmıştır.

Tablo 5'te markaların gerçek zamanlı reklam uygulamalarına ait görsel içeriğin ve türlerinin kullanım oranları görülmektedir. Bu reklam uygulamalarında en fazla kullanılan görsel içeriğin \%37,1 oranında fotoğraf olduğu belirlenmiştir. Fotoğrafin ardından diğer tercih edilen görsel içerik türlerinin, \%10'la illüstrasyon (resim), \%7,1'le animasyon olduğu tespit edilmiştir. Diğer taraftan en az kullanılan görsel içerik türü, \%1,4 ile videodur. Ayrıca reklamlarda GIF görsel içerik türüne hiç yer verilmediği, araştırmada elde edilen bir diğer bulgudur. Dikkat çekici bulgulardan birisi de, markaların \%47,1'inin reklamlarında hiç görsel içeriğe yer vermemesidir.

Tablo 5. Gerçek zamanlı reklamlarda kullanılan görsel içerik türü

\begin{tabular}{|l|c|c|}
\hline Görsel içerik türü & Frekans & Yüzde (\%) \\
\hline Fotoğraf & 26 & 37,1 \\
\hline İllüstrasyon (Resim) & 7 & 10 \\
\hline Animasyon & 5 & 7,1 \\
\hline Video & 1 & 1,4 \\
\hline GíF & 0 & 0 \\
\hline Görsel Öge Yok & 33 & 47,1 \\
\hline Toplam & $\mathbf{7 0}$ & $\mathbf{1 0 0}$ \\
\hline
\end{tabular}

$\mathrm{Bu}$ araştırmada görsel içerik özellikleriyle ilgili olarak içerikte kullanılan öğelerin durumu da incelenmiştir. Tablo 6'da görüldüğü üzere gerçek zamanlı reklamların \%31,4'ü ürün/hizmet görselini aktarırken; \%8,6's1 gündem konusuyla alakalı herhangi bir nesneye, \%7,1'i bir film/çizgifilm karakteri/maskotuna, \%4,3’ü bir grafik şekline, \%1,4'ü ise sıradan bireye içeriklerinde yer vermektedir. 
Tablo 6. Gerçek zamanlı reklamlarda kullanılan görsel öğelerin durumu

\begin{tabular}{|l|c|c|}
\hline Görsel içerikteki öğeler & Frekans & Yüzde (\%) \\
\hline Ürün/hizmet & 22 & 31,4 \\
\hline Nesne & 6 & 8,6 \\
\hline Karakter/mascot & 5 & 7,1 \\
\hline Grafik & 3 & 4,3 \\
\hline Siradan birey & 1 & 1,4 \\
\hline Topluluk & 0 & 0 \\
\hline Ünlü kişi & 0 & 0 \\
\hline Lider & 0 & 0 \\
\hline Görsel kullanılmamıştır & 33 & 47,1 \\
\hline Toplam & $\mathbf{7 0}$ & $\mathbf{1 0 0}$ \\
\hline
\end{tabular}

Tablo 7, gerçek zamanlı reklamlarda kullanılan görsel içeriklerde marka logosuna yer verilip verilmediğini göstermektedir. Görsel içeriğe sahip reklamlardan \%34,3'ü marka logosunu içerirken, \%18,6'sında ise marka logosu bulunmamaktadır.

Tablo 7. Görsel içerikte logo kullanımı

\begin{tabular}{|l|c|c|}
\hline Görsel içerikte logonun varlı̆̆ı & Frekans & Yüzde (\%) \\
\hline Logo vardır & 24 & 34,3 \\
\hline Logo yoktur & 13 & 18,6 \\
\hline İçerikte görsel kullanılmamıştır & 33 & 47,1 \\
\hline Toplam & $\mathbf{7 0}$ & $\mathbf{1 0 0}$ \\
\hline
\end{tabular}

Gerçek zamanlı reklamların görsel içerikleriyle ilgili incelenen noktalardan birisi de, görsel unsur dışında içerikte yazılı metin, slogan, etiket öğelerinin olup olmamasıdır. Tablo 8'e bakıldığında, aynı gündem konusu üzerinden tasarlanan gerçek zamanlı reklamlara ait görsel içerikte \%37,1 sloganın, \%18,6 yazılı metnin yer aldığ görülmektedir. Hiç bir marka, görsel içeriklerinde hashtage yer vermeyi tercih etmemiştir. Diğer taraftan görsel ve içerisinde sloganla yazının birlikte kullanıldığı reklam oranı \%14,3'tür. İçerisinde yazılı metin kullanmadan görsel kullanmayı tercih eden markaların oranı ise, $\% 11,4$ 'tür.

Tablo 8. Görsel içerikte yazı, slogan, hashtag kullanımı

\begin{tabular}{|l|c|c|c|}
\hline \multicolumn{2}{|l|}{ Reklam görselinin içinde...... } & Frekans & $\begin{array}{c}\text { Yüzde } \\
\text { (\%) }\end{array}$ \\
\hline \multirow{2}{*}{ Slogan } & Var & 26 & 37,1 \\
\cline { 2 - 4 } & Yok & 44 & 62,9 \\
\hline \multirow{2}{*}{ Yazı } & Var & 13 & 18,6 \\
\cline { 2 - 4 } & Yok & 57 & 81,4 \\
\hline \multirow{2}{*}{ Hashtag (etiket) } & Var & 0 & 0 \\
\cline { 2 - 4 } & Yok & 70 & 100 \\
\hline \multirow{2}{*}{ Görsel üzerinde birlikte kullanım } & Var & 10 & 14,3 \\
\cline { 2 - 4 } & Yok & 60 & 85,7 \\
\hline \multirow{2}{*}{ Görsel kullanılmamıştır } & Var & 33 & 47,1 \\
\cline { 2 - 4 } & Yok & 37 & 52,9 \\
\hline
\end{tabular}

\subsubsection{Gerçek zamanlı reklamlarda kullanılan yazılı unsur özellikleri}

Aynı gündem konusu üzerinden paylaşılan gerçek zamanlı reklamlara ait yazılı içerik unsurları; yazı metni içerisinde ürün/hizmet bilgisinin aktarılması, içerikte hashtag kullanımı, web adresi ya da twitter adreslerinin paylaşılma durumu, yazılı metin içerisinde görsel öğelerin yer alması açısından ele alınmıştır.

Yazılı metin içeriğiyle ilgili incelenen ilk konu, yazılı içerikte reklamı yapılan ürün/hizmete dair herhangi bir bilgi aktarımının yapılıp yapılmamasıdır. Analiz edilen reklamların \%52,9'unun içeriğinde ürün/hizmet bilgisine yer verilirken, $\% 47,1$ 'inde bu bilgiye rastlanmamıştır. 
Tablo 9. Yazılı içerikte ürün/hizmet bilgisinin varlı̆̆

\begin{tabular}{|l|c|c|}
\hline $\begin{array}{l}\text { Yazılı içeriğinde ürün/hizmet } \\
\text { bilgisinin varlığı }\end{array}$ & Frekans & Yüzde (\%) \\
\hline Ürün/hizmet bilgisi vardır & 37 & 52,9 \\
\hline Ürün/hizmet bilgisi yoktur & 33 & 47,1 \\
\hline Toplam & $\mathbf{7 0}$ & $\mathbf{1 0 0}$ \\
\hline
\end{tabular}

Gerçek zamanlı reklamların metninde, etiketleme yapılarak görünürlüğü arttırmayı planlayan markaların reklamlarına ait bulgular; Tablo 10'da görülmektedir. Çalışma örnekleminde, bir paylaşımda birden fazla etiketleme yapılan gerçek zamanlı reklamlar bulunmaktadır. Așağıdaki tabloya göre, aynı gündem konusundan yola çıkarak yapılan gerçek zamanlı reklamların \%97,1'inde etiketleme yapılmıştır. Yapılan bu etiketlemelerin \%90'ı gündem konusuyla, \%8,6'sı marka adı etiketiyle, $\% 2,9$ 'u marka ya da ürüne ait bir özellikle, \%1,4'ü ise mevcut reklam kampanyasının sloganıyla ilgili olduğu belirlenmiştir.

Tablo 10. Yazılı içerikte etiketleme yapılması ve türü

\begin{tabular}{|l|c|c|c|}
\hline \multicolumn{2}{|l|}{ Yazılı içerikte etiketlemenin yapılması ve türü } & Frekans & $\begin{array}{c}\text { Yüzde } \\
(\%)\end{array}$ \\
\hline \multirow{2}{*}{ Gündem etiketi } & Var & 63 & 90 \\
\hline \multirow{2}{*}{ Reklamı yapılan markanın etiketi } & Yok & 7 & 10 \\
\hline \multirow{2}{*}{ Kişi etiketi } & Var & 6 & 8,6 \\
\cline { 2 - 4 } & Yok & 64 & 91,4 \\
\hline Marka/ürün özelliğine yönelik etiket & Var & 0 & 0 \\
\cline { 2 - 4 } & Yok & 70 & 100 \\
\hline Reklam kampanyasının sloganına yönelik etiket & Var & 2 & 2,9 \\
\cline { 2 - 4 } & Yok & 68 & 97,1 \\
\hline Marka sloganı etiketi & Var & 1 & 1,4 \\
\hline Etiket & Yok & 69 & 98,6 \\
\cline { 2 - 4 } & Var & 2 & 2,9 \\
\hline
\end{tabular}

Örneklemdeki gerçek zamanlı reklamların içeriğinde normal yazılı ifade ve etiketleme dışında, başka hangi bilgilere de yer verildiği ele alınan konular arasında bulunmaktadır. Reklamların \%20'sinde web ya da Twitter adreslerine rastlanırken, \%80'inde bu adreslere yer verilmediği belirlenmiştir.

Tablo 10. Yazll içerikte web, twitter adres bilgisinin varliğ

\begin{tabular}{|l|c|c|}
\hline $\begin{array}{l}\text { Yazılı içeriğinde web, twitter } \\
\text { adres bilgisinin varlığı }\end{array}$ & Frekans & Yüzde (\%) \\
\hline Web, Twitter adresleri vardır & 14 & 20 \\
\hline Web, Twitter adresleri yoktur & 56 & 80 \\
\hline Toplam & $\mathbf{7 0}$ & $\mathbf{1 0 0}$ \\
\hline
\end{tabular}

Gerçek zamanlı reklamlarda ana görsel içeriğin yanında zaman zaman yazılı içerisinde de görsel şekiller kullanılmaktadır. Bu çalışmadan elde edilen bulgulara göre, bu uygulamaların \%8'inin metni içerisinde görsel öğeler kullanılmış, \%88,6'1nda ise kullanılmamıştır.

Tablo 11. Yazılı içerikte görsel öğelerin varlı̆̆

\begin{tabular}{|l|c|c|}
\hline $\begin{array}{l}\text { Yazılı içerikte görsel öğelerin } \\
\text { varlığı }\end{array}$ & Frekans & Yüzde (\%) \\
\hline Görsel öğeler vardır & 8 & 11,4 \\
\hline Görsel öğeler yoktur & 62 & 88,6 \\
\hline Toplam & $\mathbf{7 0}$ & $\mathbf{1 0 0}$ \\
\hline
\end{tabular}




\section{Markaların gerçek zamanlı reklamlara yönelik genel kullanım durumları}

Çalışmanın ana sorularından birisi de markalarla paylaşımda bulundukları gerçek zamanlı reklamlar arasında uyum durumunun nasıl olduğudur. Bu konuyu açıklamak için gerçek zamanlı reklamlarda yararlanılan gündem konusuyla ürün, reklamda verilen mesaj, reklamdaki görsel ve yazılı içeriğin arasındaki uyum incelenmiştir.

\subsection{Yararlanılan gündem konusu ile ürün arasındaki uyum durumu}

Analiz edilen gerçek zamanlı reklamlardaki ürün ile konu edilen gündem konusu arasındaki uyumluluk durumu, Tablo 12'de görülmektedir. Reklamların \%34,3'ünde gündem ile ürün arasında uyum olduğu, bu uyumun da yüksek düzeyde olduğu belirlenmiş̦tir. Diğer taraftan reklamların \%65,7'sinde ise herhangi bir uyuma rastlanmamıştır. Elde edilen bulgular Araştırma sorusu 2.a'nın cevabını oluşturmaktadır.

Tablo 12. Gündem konusu ile ürün arasindaki uyum durumu ve düzeyi

\begin{tabular}{|l|c|c|}
\hline $\begin{array}{l}\text { Gündem konusu ile ürün } \\
\text { arasındaki uyum durumu }\end{array}$ & Frekans & Yüzde (\%) \\
\hline Uyum vardır & 24 & 34,3 \\
\hline Uyum yoktur & 46 & 65,7 \\
\hline Toplam ile ürün & Frekans & Yüzde (\%) \\
\hline $\begin{array}{l}\text { Gündem konusu } \\
\text { arasındaki uyumun düzeyi }\end{array}$ & 24 & 34,3 \\
\hline Yüksek & 0 & 0 \\
\hline Düşük & 46 & 65,7 \\
\hline İlişki yok & $\mathbf{7 0}$ & $\mathbf{1 0 0}$ \\
\hline Toplam & & \\
\hline
\end{tabular}

\subsection{Yararlanılan gündem konusu ile reklamda verilen mesaj arasındaki uyum durumu}

Tablo 13, gerçek zamanlı reklamlarda yararlanılan gündem konusu ile reklamda verilen mesaj arasındaki uyumluluk durumunu göstermektedir. Elde edilen bulgulara göre, reklamların \%58,6'ında gündem konusu ile reklamda verilen mesaj arasinda uyum olduğu; bu uyumluluk durumunun da \%42,9'unun yüksek, \%14,3'nün ise düşük düzeyde olduğu belirlenmiştir. Ancak reklamların \%42,9'unda reklam mesajı ile gündem konusu arasında herhangi bir ilişkinin olmadığı tespit edilmiştir. Elde edilen bulgular Araştırma sorusu 2.b'nin cevabını oluşturmaktadır.

Tablo 13. Gündem konusu ile reklam mesajı arasındaki uyum durumu ve düzeyi

\begin{tabular}{|l|c|c|}
\hline $\begin{array}{l}\text { Gündem konusu ile reklam mesajı } \\
\text { arasındaki uyum durumu }\end{array}$ & Frekans & Yüzde (\%) \\
\hline Uyum vardır & 41 & 58,6 \\
\hline Uyum yoktur & 29 & 41,4 \\
\hline Toplam & $\mathbf{7 0}$ & $\mathbf{1 0 0}$ \\
\hline $\begin{array}{l}\text { Gündem konusu ile reklam mesajı } \\
\text { arasındaki uyumun düzeyi }\end{array}$ & Frekans & Yüzde (\%) \\
\hline Yüksek & 30 & 42,9 \\
\hline Düşük & 10 & 14,3 \\
\hline İlişki yok & 30 & 42,9 \\
\hline Toplam & $\mathbf{7 0}$ & $\mathbf{1 0 0}$ \\
\hline
\end{tabular}

\subsection{Yararlanılan gündem konusu ile reklamdaki görsel içerik arasındaki uyum durumu}

Gerçek zamanlı reklamların tasarımında yararlanılan gündem konusu ile reklamın görsel içerik arasındaki uyuma ve düzeyine ait bulgular, Tablo 14'te görülmektedir. Bu bulgular doğrultusunda, analiz edilen reklamların \%35,7'sinde gündem konusu ile reklamın görsel içeriği arasında uyumun olduğu; var olan uyumluluk düzeyinin ise \%22,9'unun yüksek, \%12,9'unun düşük düzeyde olduğu söylenebilmektedir. Diğer taraftan içeriğinde görsel bulunan reklamların \%18,6'1nda görsel içerikle 
gündem konusu arasında herhangi bir ilişki yoktur. Elde edilen bulgular Araştırma sorusu 2.c'nin cevabını oluşturmaktadır.

Tablo 14. Gündem konusu ile reklamdaki görsel içerik arasındaki uyum durumu ve düzeyi

\begin{tabular}{|l|c|c|}
\hline $\begin{array}{l}\text { Gündem konusu ile görsel içerik } \\
\text { arasındaki uyum durumu }\end{array}$ & Frekans & Yüzde (\%) \\
\hline Uyum vardır & 25 & 35,7 \\
\hline Uyum yoktur & 13 & 18,6 \\
\hline Görsel içerik yok & 32 & 45,7 \\
\hline Toplam & $\mathbf{7 0}$ & $\mathbf{1 0 0}$ \\
\hline $\begin{array}{l}\text { Gündem konusu ile görsel içerik } \\
\text { arasındaki uyumun düzeyi }\end{array}$ & Frekans & Yüzde (\%) \\
\hline Yüksek & 16 & 22,9 \\
\hline Düşük & 9 & 12,9 \\
\hline İlişki yok & 13 & 18,6 \\
\hline Görsel içerik yok & 32 & 45,7 \\
\hline Toplam & $\mathbf{7 0}$ & $\mathbf{1 0 0}$ \\
\hline
\end{tabular}

\subsection{Yararlanılan gündem konusu ile reklamdaki yazılı içerik arasındaki uyum durumu}

Çalışmada son olarak incelenen konu, gerçek zamanlı reklamların tasarımında faydalanılan gündem konusu ile reklamın yazılı içerik arasındaki uyumluluk durumudur. Tablo 15 'teki bulgular, reklamların \%58,6'sında gündem konusuyla yazılı içeriğin uyumlu olduğunu; var olan uyumun da \%42,9'unun yüksek, \%14,3'ünün de düşük düzeyde olduğunu göstermektedir. Ayrıca elde edilen bir diğer bulgu da, reklamların \%42,9'unda gündem konusuyla yazılı içerik arasında herhangi bir ilişkinin olmamasıdır. Elde edilen bulgular Araştırma sorusu 2.d'nin cevabını oluşturmaktadır.

Tablo 15. Gündem konusu ile reklamdaki yazılı içerik arasındaki uyum durumu ve düzeyi

\begin{tabular}{|l|c|c|}
\hline $\begin{array}{l}\text { Gündem konusu ile yazılı içerik } \\
\text { arasındaki uyum durumu }\end{array}$ & Frekans & Yüzde (\%) \\
\hline Uyum vardır & 41 & 58,6 \\
\hline Uyum yoktur & 29 & 41,4 \\
\hline Toplam & $\mathbf{7 0}$ & $\mathbf{1 0 0}$ \\
\hline $\begin{array}{l}\text { Gündem konusu ile yazılı içerik } \\
\text { arasındaki uyumun düzeyi }\end{array}$ & Frekans & Yüzde (\%) \\
\hline Yüksek & 30 & 42,9 \\
\hline Düşük & 10 & 14,3 \\
\hline İlişki yok & 30 & 42,9 \\
\hline Toplam & $\mathbf{7 0}$ & $\mathbf{1 0 0}$ \\
\hline
\end{tabular}

\section{TARTIŞMA VE SONUÇ}

Gerçek zamanlı reklamlar, dijital platformlarda gerçek zamanlı gündem içeriğini markalar/ürünler lehine çevirerek anlık olarak paylaşılan ve tüketicilerle etkileşime geçmek için yapılan popüler reklam uygulamasıdır. İnternet reklamcılığında genellikle kullanıcı deneyimini keserek, tüketicilerin reklamdaki marka/ürüne odaklanmasına çalışılmaktadır. Üstelik böyle bir uygulamada, kullanıcı deneyimi kesintiye uğratıldığı için istenmeyen, olumsuz sonuçlarla karşılaşılabilmektedir. Gerçek zamanlı reklamlarda ise tam tersi bir durum söz konusudur. Tüketicilerin dikkati zaten gündem konusuna odaklanmış durumdadır. Dolayısıyla ne olduğunu bildikleri için, gündeme yönelik gönderme olsa bile konuyu hemen farkedebilmektedirler. Bu bağlamda gerçek zamanlı reklamlar, katılımı kışkırtmak için zaten çalışmakta olan bir odaktan yararlanmaktadır.

Sahip olduğu özellikler ve sunduğu avantajlar nedeniyle, gerçek zamanlı reklamlar markalar tarafindan yoğun oranda kullanılmaktadır. Diğer taraftan aynı gündem konusunu ele alan gerçek zamanlı 
reklamlarla ilgili bilinmeyen birçok nokta bulunmaktadır. Örneğin; gündem reklam içeriğini oluşturduğu için hangi ürün kategorilerinde bu uygulamanın yoğun olarak kullanıldığı, markaların hangi stratejik amaç için bu uygulamaları kullandığı, gündem mesajıyla marka mesajını birleştirmek için en çok hangi içerik türünün tercih edildiği gibi gerçek zamanlı reklamların markalar tarafından genel kullanım durumları bilinmemektedir. Dahası bu uygulamalar gündemden yola çıkılarak hazırlanmasına rağmen markaların ürün kategorisi, aktarılan reklam mesajı, reklamın görsel ve yazılı metin içeriği uyum düzeyinin nasıl olduğu gibi uygulamanın başarısını etkileyebilecek bazı önemli noktalarla ilgili de bilgi açığı bulunmaktadır. Bu çalışmayla elde edilen sonuçlar, markaların Twitter'daki gerçek zamanlı reklam kullanımlarına yönelik genel durumlarıyla ilgili bilgiler ortaya koymakta ve birçok açıdan bu uygulamaları doğru kullandıklarını göstermektedir.

Aynı gündem konusunu ele alan gerçek zamanlı reklamların analiz edildiği araştırma sonuçlarına göre, markalar genellikle marka imajını desteklemek ve ürün/hizmetle ilgili bilgi aktarmak için bu reklam uygulamasından faydalanmıştır. Bazı markalar ise, tüketicilerle bağ kurmak veya ürün satışını desteklemek amacıyla kullanmayı tercih etmiştir. Bu sonuçlar, markaların gerçek zamanlı reklamların gerçekleştirebileceği hedefler belirlediğini göstermektedir (Bknz s.5). Analiz edilen reklamlardaki ürün, reklam mesajı, görsel ve yazılı metinden yola çıkılarak bu hedefleri seçme nedeni, kısaca şu şekilde açıklanabilmektedir: Sosyal medya ortamları bireylerde olduğu gibi, markalarla müşterileri/tüketicileri arasında iletişim ve etkileşimi gerçekleştirmek için çeşitli olanaklar sunmaktadır. Özellikle her ortama özgü dikkat çekici içerik tasarımı aracılı̆̆ıyla hedef kitlelerinin ilgilerini çekerek onlarla etkileşim kurabilmektedirler. Sosyal medyada paylaşılan gerçek zamanlı reklamlar da, gündemin çekiciliğinden faydalanarak hedef kitlenin dikkatini markaya/ürüne çekmeye, bilinen bir markaysa marka imajını desteklemeye; eğer yeni bir ürün söz konusuysa o ürüne yönelik farkındalığı artırıp bilgilendirmeye çalışmaktadır. Ayrıca gündemin dikkat çekici, esprili, ironik vb şekilde kullanılarak reklam mesajına dönüştürülmesi, tüketicinin ilgi duyduğu gündemin belirlenerek onun ihtiyacı üzerinden gündemin yeniden kurgulanması; tüketicinin ilgisini çekip sempatisini kazanmak amacıyla yapılmaktadır. Dolayısıyla analiz edilen reklamlardan bazılarında, hedef kitlelerin zihninde gerçek zamanlı reklamların olumlu etkisi, marka imajına transfer olması beklenmiştir. Yine bu reklamların bazılarında ürün/hizmetlerle ilgili bilgi verilerek ürünün tanınması sağlanrken, bir kısmında hedef kitlelerle marka arasında bağ kurulmaya çalışılmıştır. Sonuç olarak her reklam uygulamasında olduğu gibi, bu uygulamalarda da dolaylı olarak nihai amaç satışın gerçekleştirilmesidir. Özellikle bu çalışmadaki gerçek zamanlı reklamların yazılı metin bölümüne, ürünle ilgili web sitesine ait linkler konularak daha fazla bilgi sunulup hedef kitle satın almaya yönlendirilmiştir.

Analize dahil edilen gerçek zamanlı reklamların içerik öğelerine yönelik sonuçlara bakıldığında ise, görsel içeriğin neredeyse kullanılmadığı; daha çok ya sadece yazılı metin içeriğinin ya da görsel ve yazılı metin içeriğinin birlikte kullanıldığı görülmektedir. Bu sonucun birincil nedeni olarak, reklamların paylaşıldığı sosyal medya ortamı olan Twitter'dan kaynaklandığı düşünülmektedir. Twitter başlangıçta sadece yazılı metin içeriklerinin paylaşılabildiği, zaman içerisinde görsel öğe paylaşım özelliğinin de eklendiği sosyal medya platformudur. 280 karaktere kadar yazılı metin içeriği oluşturulabilmektedir. Hem bireylerin hem de markaların gündemi yakından takip edebildiği ve gündemle ilgili anlık paylaşım yapabildiği bu platform, içerikleri, etkileşim biçimleri, etiketleme, anahtar kelime kullanımı, kendine özgü terminolojisi ile diğer sosyal medya platformlarından farklılaşmaktadır. Twitter özellikle gündemi takip etmek ya da gündemde yer alabilmek için kullanılmaktadır. Sahip olduğu tüm bu özellikler ve sunduğu firsatlar nedeniyle birçok birey gibi, markalar da burada olmayı tercih etmektedir. Gerçek zamanlı reklamların var olma nedeni ve dayandığı kuram dikkate alındığında, bu uygulamalar için en uygun sosyal medya platformu Twitter'dır. Twitter'ın sahip olduğu özellikler nedeniyle, analize dahil edilen reklamlarda daha çok yazılı metin ya da görsel-yazılı metnin bir arada kullanıldığı düşünülmektedir. Görselliğin eklenmesinin nedeni olarak, görsel içeriklerin dikkat çekiciliğinin daha fazla olması; yazılı metin içeriğinin kullanılma nedeni olarak da gündem konusuna gönderme yapıldığı için hedef kitlenin daha iyi ve doğru anlayabilmesi, gündem konusuyla ilgili etiketlemelerin paylaşılmasının reklamın gündeme daha fazla ve hızlı gelmesi düşüncesinden kaynaklandığı varsayllmaktadır.

Araştırma kapsamında incelenen bir diğer konu, gerçek zamanlı reklam kullanımının hangi ürün kategorileri tarafindan tercih edildiğidir. Daha önce de belirtildiği gibi araştırmaya gündemdeki elektrik 
kesintisini konu alan ürünlere ait reklamlar dahil edilmiştir. Elde edilen sonuçlara göre, en fazla gerçek zamanlı reklam yapılan ürün kategorisi büyük oranda gıdadır. Bu kategoriyi oldukça geriden onlinefiziki perakende mağazaları ve otomotiv/yan ürünler kategorisi takip etmektedir. Elektrik kesintisi gündeminden faydalanarak kendisini öne çıkarmak isteyen kategorilerin, bu kategoriler olması çok şaşırtıcı görülmüştür. Araştırma öncesinde, gündem konusu göz önüne alındığında, daha çok beyaz eşya, bilgi/iletişim teknolojileri, eğlence/medya gibi kategorilerin daha fazla öne çıkacağı tahmin edilmekteydi. Bu sonuçlar, ürün türü ne olursa olsun birçok kategorinin gerçek zamanlı reklamlardan faydalandığını göstermektedir.

$\mathrm{Bu}$ noktada ürünün ve reklamda verilen mesajın, gündemle uyumlu olması çok önem taşımaktadır. Çünkü ancak uyumlu olduğu takdirde, hedef kitle bağlantıyı kurabilmekte, hedef kitle üzerinde olumlu etkinin bırakılması mümkün olabilmekte; böylece reklamdan beklenen amaçlar gerçekleşebilmektedir. Araştırma sonuçları, reklamlardaki ürünle gündem konusu arasında çoğunlukla uyumun olmadığını, hiçbir ilişkiye rastlanmadığını göstermektedir. Bu çok riskli bir durumdur. Çünkü böyle bir durumda eğer reklamda aktarılmak istenen mesajla gündem konusu arasında herhangi bir uyum olmazsa; hedef kitle aradaki bağlantıyı kuramayabilir, reklamı anlamsız ve saçma olarak değerlendirerek olumsuz tepkiler verebilir. Sonuç olarak böyle bir durumda marka ya da ürün, hem tutum hem de davranış bazında hiç istenmeyen tüketici tepkilerine maruz kalabilmektedir. $\mathrm{Bu}$ durumun oluşmaması için markalar ya ürünle uyumlu, hedef kitlenin de ilgisini çekebileceği bir gündem konusu seçmeli ya da eğer uyumsuzluk varsa, reklam mesajını çok zekice, etkileyici ve uyumlu olabilecek şekilde tasarlaması gerekmektedir.

Araştırma kapsamında aktarılmak istenen reklam mesajı ve gündem arasındaki uyum durumuna bakıldığında ise, çok çarpıcı bir sonucun olduğu görülmektedir. Analiz edilen gerçek zamanlı reklamlarda aktarılmak istenen reklam mesajıyla gündem konusu arasında genellikle uyumun olduğu; üstelik bu uyum düzeyinin de yüksek olduğu belirlenmiştir. Bu sonuçlar markaların reklamlarında gündemle aktarmak istediği mesajı doğru kurguladığını, her ne kadar ürün bazında herhangi bir uyum olmasa da reklam mesajı açısından başarılı bir içerik oluşturduğunu, ürün-gündem arasındaki uyumsuzluğu kapatarak hedef kitle tarafından bu uyumsuzluğun hissedilmemesini sağlayabileceğini göstermektedir. Başka bir ifadeyle mesajın daha fazla ön plana çıkarak, reklamdan beklenen başarıya ulaşılabileceği, başlangıçta oluşan riskin ortadan kaldırılabileceği düşünülmektedir. Diğer taraftan bu sonuçların yapılacak yeni araştırmalarla tüketici açısından da test edilmesi ve sonuçların karşılaştırılması önerilmektedir. Ayrıca araştırma sonuçlarında her ne kadar reklam mesajı ve gündem arasındaki uyumluluk oranı yüksek çıksa da; reklam mesajıyla gündem arasında uyumsuzluk olan gerçek zamanlı reklam oranının da küçümsenemeyecek düzeyde yüksek olduğu $(\% 41,4)$ görülmektedir. Bu nedenle bir çok markanın gerçek zamanlı reklam tasarlarken, kullanılan kuram ve stratejiye uygun hareket etmeyip, sadece rakiplerden geri kalmamak için popüler olan bu uygulamayı yapmış markalar arasında olduğu söylenebilmektedir. Bu durum da reklamın başarı düzeyine olumsuz yansıyabilmektedir.

Elbette gerçek zamanlı reklamların başarılı olması sadece aktarılmak istenen mesajla gündem konusu arasındaki uyuma bağlı değildir. Başarı için bir diğer önemli nokta, bu mesajın aktarılmasında kullanılan görsel ve yazılı içerikle gündem konusu arasında da uyumun olmasıdır. Bu uyumla ilgili araştırma sonuçlarından önce, gerçek zamanlı reklamların genel olarak görsel ve yazılı içerik özelliklerine değinilmiştir.

Reklamların görsel unsur türlerine bakıldığında, çok yüksek oranda fotoğrafin kullanıldığı görülmektedir. Fotoğrafı, arada oldukça fark olarak resim ve animasyon takip etmektedir. Başarılı gerçek zamanlı reklamların özellikleri arasında dikkat çekici olması, ilgi uyandırması ve paylaşılabilir olması bulunmaktadır. Twitter genel olarak yazı ağırlıklı olduğundan, kullanılan görsellerin bu metni desteklemesi amacıyla genel olarak fotoğraf kullanıldığı tahmin edilmektedir. Ayrıca Twitter ortamında akışın çok hızlı ve anlık olması nedeniyle, paylaşılan görselin ilk firsatta dikkati çekebilmesi gerekmektedir. Video tarzı hareketli bir içerik söz konusu olduğunda, platformun yapısı ve kullanım şekli nedeniyle dikkati odaklamada sorun yaşanabilmektedir. Oysa fotoğrafta başarılı bir görsel içerik tasarlandığında, ilk bakışta istenen dikkatin elde edilebilmesi mümkün olabilmektedir. Ayrıca reklamın yayılarak gündeme yerleşebilmesi için kolaylıkla paylaşılabilir olması da önemlidir. Fotoğraf dışında 
hareketli bir görsel içeriğin olması, reklamın kolayca paylaşılmasına engel olabilir. Bu nedenlerden dolayı markaların da, reklamlarında fotoğraf kullanmayı tercih etmiş olabileceği düşünülmektedir.

Reklamlarda yer alan görsel içeriklerin özellikleriyle ilgili sonuçlar incelendiğinde ise; görsellerde logoya yer verildiği, sloganın olmadığı, ana yazılı metin dışında görseli destekleyici metnin kullanılmadığı görülmektedir. Ayrıca görsel içerikte kullanılan görsel öğenin, en fazla ürün/hizmet olduğu, bunu oldukça geriden nesnenin takip ettiği belirlenmiştir. Gerçek zamanlı reklamların kullanılma nedenleri arasında en fazla ürün/hizmet bilgisi aktarmanın olduğu düşünüldügünde, görsel öğede ürün/hizmet görselinin kullanılması normal bir durumdur. Diğer taraftan markaların marka imajını desteklemek için de gerçek zamanlı reklamlardan faydalandığı göz önüne alındığında, görselde metafor olarak nesne kullanımının yapıldığı, ayrıca logonun gösterilmesiyle imaja destek verilmeye çalışıldığı düşünülmektedir. Genel olarak yazılı metinde ana mesajın verildiği, görsele ise metni desteklemek için yer verildiği varsayılmaktadır.

Gerçek zamanlı reklamlardaki yazılı unsurların özellikleriyle ilgili sonuçlara bakıldığında ise, yine önemli bilgilerin olduğu görülmektedir. Öncelikle reklamlardaki yazılı metin içeriğinde çoğunlukla ürün/hizmet bilgisine yer verildiği belirlenmiştir. Reklamı en çok yapılan ürünlerin gida olduğu düşünüldüğünde, hedef kitlenin bu ürünlerle ilgili bilgi sahibi olmaları, ardından da satın alma davranışı gerçekleştirmeleri beklentisinin bulunduğu düşünülmektedir. Bu nedenle de reklamlarda ürün/hizmet bilgisine yer verilmiş olabilir. Ayrıca yazılı metinde çoğunlukla etiketin kullanıldığı, az sayıda web, twitter adresi gibi bilgilerin yer aldığ 1 , çok az sayıda görsel öğelerin kullanıldığ görülmektedir. Ek olarak etiket kullanım türleri arasında da en çok gündem etiketi kullanıldığı tespit edilmiştir. Gündemin popülerliğinden faydalanma ve bu doğrultuda yayılma amacı taşıyan bir reklam uygulamasının, gündem konusunu etiketlemesi ve böylece gündemi yazan herkesin karşısına markanın da çıkma olasılığını artırarak gündeme yerleşme ihtimalini artırmak istemesi doğal bir durumdur. Her ne kadar yazilı metin içerisinde az sayıda görsel olsa da, kullanılan görsellerin emoji, animatik görseller olduğu göz önüne alındığında, marka adına mesajın daha sempatik ve sevimli görünerek, hedef kitleye olumlu aktarımın yapılması düşünülmüş olabilir.

Reklamdaki görsel ve yazılı öğelerle gündem konusu arasındaki uyum durumuna bakıldığında, hem kullanılan görsel içeriklerin hem de yazılı metin içeriğinin gündem konusuyla yüksek düzeyde uyumlu oldukları belirlenmiştir. Bu sonuç, gerçek zamanlı reklamların taşıması gereken en önemli özelliklerden ikisine sahip olduğunu göstermektedir. Çünkü genel reklam tasarımının en önemli özellikleri arasında, aktarılmak istenen mesajın net olması, bu mesajın hem görsel hem de yazılı içeriklerle hedef kitlenin anlayabileceği şekilde aktarılması bulunmaktadır. Gerçek zamanlı reklamlar söz konusu olduğunda ise, görsel ve yazılı içeriğin birbirini destekler nitelikte reklam mesajını doğrudan aktarabilmesinin yanı sıra, her iki içeriğin gündem konusuyla bağlantısının da olması gerekmektedir. Bu çalışma sonucu, gündem bağlantısının hem görsel hem de yazılı içerikte yüksek düzeyde bağlantılı olduğunu göstermektedir. $\mathrm{Bu}$ bağlantının olması, analiz edilen reklamların gerçek zamanlı reklamların stratejisine uygun olarak tasarlandığını, kuramın temeliyle de birebir örtüştüğünü göstermektedir. Bu durum, reklama yönelik beklentilerin gerçekleşme olasılı̆̆ını arttırmaktadır.

Gerçek zamanlı reklamların başarısında, sadece içerik öğelerinin gündem konusuyla uyum olması ve sosyal medya ortamına uygun tasarlanması tek başına yeterli değildir. Her reklam uygulamasında olduğu gibi yaratıcı olması da, bu uygulamaların başarısında en önemli özelliklerden birisidir. Diğer taraftan bu çalışma gündem oluşturma kuramı temelinde kurgulandığı için, analiz edilen gerçek zamanlı reklamların görsel ve yazılı içeriklerinde gündemle bağlantılı olup olmadığının incelenmesi esas alınmıştır. Yaratıcılık niteliğinin incelenmemesi, araştırmanın sınırlılıkları arasında yer almaktadır. Bu bağlamda gerekli literatüre dayandırılarak gerçek zamanlı reklamların yaratıcılık niteliğinin yeni araştırmalarla incelenmesi önerilmektedir.

Sonuç olarak markaların ürünleri gündeme uygun olmasa da aktardıkları mesaj ve bu mesajı aktarmak için tasarladıkları görsel ve yazılı içerik bakımından değerlendirildiğinde, gündemin reklam mesajına başarılı bir biçimde dönüştürülebildiği görülmektedir. Ürünün gündem konusuyla uyumlu olması farketmeksizin, markalar reklam içeriklerini Twitter ortamının doğasına uygun biçimde tasarlamakta; gündem konusuyla dikkat çekici, uyumlu ve bağlantılı biçimde bu reklam uygulamalarını kurgulayabilmektedir. Bu doğrultuda markaların gerçek zamanlı reklamları doğru amaçlar için kullanma bilincine sahip oldukları; aynı zamanda gerçek zamanlı reklamların, tasarımında kullanılması gereken stratejiye, var olma nedenine ve dayandığı kurama uygun biçimde kullandıkları, gerekli tasarım 
özelliklerine sahip gerçek zamanlı reklamlar yaptıkları söylenebilmektedir. Diğer taraftan aktarılmak istenen reklam mesajı ve bu mesajın yazılı içerikte aktarılması açısından, gerçek zamanlı reklamları kurama ve tasarım stratejisine uygun olarak yapamayan marka sayısının da yüksek olduğu söylenebilmektedir. Bu durum; hala gerçek zamanlı reklam uygulamalarının popülerlikten faydalanarak çoğunluğa ayak uydurmak için yapılamayacağı, her iletişim çalışmasında olduğu gibi bu uygulamaların da belli strateji ve temele dayalı tasarlanması gerektiği bilincine sahip olmayan markaların olduğunu göstermektedir. Markalara çok önemli kazanımlar getiren bir reklam uygulaması olsa da, diğer reklam çalışmalarıyla benzer biçimde gerçek zamanlı reklamlar da doğru temeller üzerine kurgulandığında beklentileri karş1layabilme gücüne sahiptir. Kuramın reklamdaki geçerliliğine göre; reklamda gündem seçimi ve bu gündemin sunum biçimiyle birlikte insanların düşünme odağı etkilenebilmektedir. $\mathrm{Bu}$ bağlamda reklam mesajının, görsel ve yazılı içeriğin gündeme göre tasarımı ve uyumu önem taşımaktadır.

Bilgilendirme / Acknowledgement: Bu çalışmada araştırma ve yayın etiğine uyulmuştur.

\section{KAYNAKÇA}

Atabek, N. (2012). Gündem belirleme yaklaşımı. İstanbul Üniversitesi Illetişim Fakültesi Dergisi, (7), 155-174. 13.10.2019 tarihinde https://dergipark.org.tr/tr/pub/iuifd/issue/22884/244799 adresinden erişildi.

Bazarcı, S. ve Mutlu, B. (2017). Yeni bir pazarlama iletişimi yaklaşımı olarak gerçek zamanlı pazarlama: Markaların sosyal medyadaki paylaşımları üzerinde bir inceleme. I. Uluslararası İletişimde Yeni Yönelimler Konferansı, Nisan, İstanbul.

Cohen, B. C. (1963). The press and foreign policy. New Jersey: Princeton University Press.

Clow, K.E. ve Baack, D. (2016). Bütünleşik reklam, tutundurma ve pazarlama iletişimi. (G. Öztürk, Çev.). Ankara: Nobel Yayınları.

Concannon, L. (2018). How to succeed at real time marketing in social media. 14.10.2019 tarihinde https://sysomos.com/2018/07/16/how-to-succeed-at-real-time-marketing-in-social-media/ adresinden erişildi.

Çekiç Akyol, A. (2011). Reklam mesajlarında bilgilendirici içerik: Dergi reklamları üzerine bir içerik analizi. Yayınlanmamış doktora tezi, Selçuk Üniversitesi, Konya.

Dearing, J.W. ve Rogers, E.M. (1996). Communication concepts 6: Agenda-setting. Thousand Oaks: Sage.

Demir, T. (2019). Reklamda bir anlatı motifi olarak gündem kuramı uygulaması ve Kiğılı örneği. Halkla İlişkiler ve Reklamcllk E-dergisi, 2(2), Ekim. 02.011.2019 tarihinde https://dergipark.org.tr/tr/pub/hire adresinden erişildi.

Dieguez, V.S. (2015). Are you overlooking the most valuable real-time marketing strategy? 13.11.2019 tarihinde http://www.convinceandconvert.com/digital-marketing/are-you-overlooking-the-mostvaluable-real-time-marketing-strategy/ adresinden erişildi.

Elden, M. ve Özdem, Ö. O. (2015). Reklamda görsel tasarım - Yaratıcıllk ve sanat. İstanbul: Say Yayınları.

Eralp, M.Ü. (2018). Sosyal medyada gerçek zamanlı pazarlamanın rolü: Hızlı tüketim markalarının twitter paylaşımları üzerine bir inceleme. Yayınlanmamış yüksek lisans tezi, İstanbul Kültür Üniversitesi, İstanbul.

Donald L. Shaw ve Maxwell E. M. (1977). The emergence of american political issues: The agenda setting function of the press. St. Paul: West Publishing Company.

Håkansson, D.\& Bengtsson, T. (2014). Real-time marketing effects on brands in social media. Bachelor Thesis, Halmstad University, Halmstad. 
Hazaparu M. A. (2014). Setting the agenda in advertising: Understanding ethical dilemmas from a communicative perspective. Comunicação e Sociedade, 25, 328-342. 14.10.2019 tarihinde file:///C:/Users/lenovo/Downloads/Setting_the_agenda_in_advertising_unders.pdf adresinden erişildi.

Kerns, C. (2014). Trendology - Building an advantage through data-driven real-time marketing. New York: Palgrave Macmillan. 13.10.2019 tarihinde https://www.palgrave.com/gp/book/9781137479556 adresinden erişildi.

Krippendorff, K. (2004). Content analysis: An introduction to its methodology. California: Sage Publications.

Macy, B. ve Thompson, T. (2011). The power of real-time social media marketing: How to attract and retain customers and grow the bottom line in the globally connected world. New York: McGraw-Hill.

Miller, M. (2013). Real-time marketing smarts: Companies killing it with off-the-cuff content. 13.11.2019 tarihinde http://www.toprankblog.com/2013/04/real-time-marketing-smarts/ adresinden erişildi.

Neuman, W. L. (2009). Toplumsal araştırma yöntemleri, nitel ve nicel yaklaşımlar. (S. Özge, Çev.), İstanbul: Yayın Odası Yayınları.

O'Connor, P. (2015). Does real-time marketing work on social media? 15.11 .2019 tarihinde https://socialmediaweek.org/blog/2015/08/real-time-marketing/ adresinden erişildi.

Scott, D. M. (2010). Real-time marketing \& PR. New Jersey: John Wiley \& Sons.

Şahin, E. ve A. Şentürk, Z. (2018). Gündem oluşturma teorisi bağlamında özel günleri konu alan reklamların analizi. International Journal of Social Sciences and Education Research, 4(4), 698720 .

Severin, W.J. ve Tankard, Wr. J.W. (1994). Illetişim kuramlart: Kökenleri, yöntemleri ve kitle iletişsim araçlarında kullanımları. (A. A. Bir ve N. S. Sever, Çev.), Eskişehir: Kibele Sanat Merkezi.

Şit, Z. (2018). Yaratıcı içerikler, etkili sonuçlar: Real time marketing. 15.10 .2019 tarihinde https://www.brandingturkiye.com/yaratici-icerikler-etkili-sonuclar-real-time-marketing/ adresinden erişildi.

Türkden, D. K. (2013). Dijital platformlarda sosyal markaların inşast: markaların sosyal medya kullanımı üzerine bir araştırma. Yayınlanmamış doktora tezi, Marmara Üniversitesi, İstanbul.

Üstündağ, M. E. (2018). Sosyal medyada gerçek zamanlı pazarlamanın rolü: Hızlı tüketim markalarının twitter paylaşımları üzerine inceleme. İstanbul Kültür üniversitesi, İstanbul.

Yegen, Ceren. (2014) Medyanın kamuoyu oluşturma ve gündem belirleme rolü üzerine: Serai Sierra haberleriyle oluşturulan yapay gündem. Dicle Üniversitesi SBE Dergisi, 6(12), 21-46.

Yılmaz, A. (2018). Yeni bir pazarlama iletişimi yaklaşımı gerçek zamanlı pazarlama: Otomobil markalarının geleceğe dönüş günü sosyal medya pratikleri. Erciyes İletişim Dergisi, 5(4), Temmuz, 423-446.

Yüksel,E. (2007). Kamuoyu oluşturma ve gündem belirleme kavramları nerede kesişmekte, nerede ayrilmaktadır? Sosyal Bilimler Dergisi, 1, 571-586.

Weaver, D. H. Doris; Graber, A.;McCombs, Maxwell E. ve Chaim, H. E.(1981). Media agenda setting in a presidential election. New York:Praeger.

15.10.2019 tarihinde https://www.webolizma.com/gercek-zamanli-pazarlama-nedir/ adresinden erişildi.

tarihinde

https://twitter.com/Koctas/status/1017453544088244224?ref_src=twsrc\%5Etfw\%7Ctwcamp\%5 Etweetembed\%7Ctwterm\%5E1017453544088244224\&ref_url=https\%3A\%2F\%2Fmediacat.co $\mathrm{m} \% 2 \mathrm{Fkoctastan}$-vida-yorumu $\% 2 \mathrm{~F}$ adresinden erişildi. 